\title{
Predicting distributions of rare species: the case of the false coral snake Rhinobothryum bovallii (Serpentes: Colubridae)
}

\author{
Fabio Leonardo Meza-Joya, ${ }^{1,2}$ Julián Andrés Rojas-Morales, ${ }^{3}$ and Eliana Ramos ${ }^{1,2}$ \\ ${ }^{1}$ Universidad Industrial de Santander, Escuela de Biología, Grupo de Investigación en Biotecnología Industrial y Biología \\ Molecular, Parque Tecnológico Guatiguará. Km 2 vía al Refugio, Piedecuesta, Santander, Colombia. E-mail: fabio.meza@ \\ correo.uis.edu.co. \\ ${ }^{2}$ Colombia Endémica, Asociación para el Estudio y la Conservación de los Recursos Naturales. Bucaramanga, Santander, \\ Colombia. \\ ${ }^{3}$ Corporación Universitaria Santa Rosa de Cabal (UNISARC), Facultad de Ciencias Básicas, Campus Universitario El Jazmín. \\ Km 4 Vía Santa Rosa de Cabal, Chinchiná, Risaralda, Colombia.
}

\begin{abstract}
Predicting distributions of rare species: the case of the false coral snake Rhinobothryum bovallii (Serpentes: Colubridae). Typically, the lack of enough high-quality occurrence data makes it difficult to define the geographic distribution of rare species. However, species distribution models provide a powerful tool for biodiversity management, including efforts to predict the distributions of rare species. Herein, new and historical data are used to model the distribution of the False Tree Coral snake, Rhinobothryum bovallii. The prediction map reveals a disjunct distribution for this species, from the Central American Isthmus to the northwestern portion of South America, with the species occupying lowlands and premontane forests below about $1500 \mathrm{~m}$ elevation. We identified $491,516 \mathrm{~km}^{2}$ of suitable habitat for $R$. bovallii (minimum training presence threshold of 0.424 ) and 59,353 $\mathrm{km}^{2}$ of core habitat, with concentrations in three relatively isolated core areas (10-percentile training presence threshold of 0.396), as follow: (1) a "northern core" along the Pacific and Caribbean coasts of Panama; (2) a "central core" in the Middle Magdalena Valley in Colombia; and (3) a "southern core" in the Ecuadorian Chocó. The occurrence of this species has a strong positive association with low precipitation seasonality, high precipitation in the warmest quarter, and low variability in annual temperature. Xeric and semiarid areas are unsuitable for this species and may pose environmental barriers limiting its distributional range. These results may lead to the discovery of additional populations of $R$. bovallii, identify priority survey areas, and by determining the extent of its natural habitat promote effective conservation strategies.
\end{abstract}

Keywords: core habitat areas, disjunct distribution, marginal habitat, species distribution models. 


\begin{abstract}
Resumo
Prevendo distribuições de espécies raras: o caso da falsa cobra coral Rhinobothryum bovallii (Serpentes: Colubridae). Normalmente, a falta de dados de ocorrência de alta qualidade suficientes torna difícil definir a distribuição geográfica de espécies raras. No entanto, os modelos de distribuição de espécies fornecem uma ferramenta poderosa para a gestão da biodiversidade, incluindo esforços para prever a distribuição de espécies raras. Aqui, dados novos e históricos são usados para modelar a distribuição da serpente Rhinobothryum bovallii. O mapa de previsão revela uma distribuição disjunta para essa espécie, do Istmo da América Central à porção noroeste da América do Sul, com a espécie ocupando terras baixas e florestas pré-montanas abaixo de cerca de $1.500 \mathrm{~m}$ de altitude. Identificamos $491.516 \mathrm{~km}^{2}$ de habitat adequado para $R$. bovallii (limite de corte de presença mínima de treino de 0,424$)$ e $59.353 \mathrm{~km}^{2}$ de habitat central, com concentrações em três áreas centrais relativamente isoladas (limite de corte de 10-percentil de presença de treino de 0,396), como segue: (1) um "núcleo norte" ao longo das costas do Pacífico e do Caribe do Panamá; (2) um "núcleo central" no Vale do Médio Magdalena, na Colômbia; e (3) um "núcleo sul" no Chocó equatoriano. A ocorrência dessa espécie tem forte associação positiva com a baixa sazonalidade da precipitação, alta precipitação no trimestre mais quente e baixa variabilidade na temperatura anual. Áreas xéricas e semiáridas são inadequadas para essa espécie e podem representar barreiras ambientais que limitam sua faixa de distribuição. Esses resultados podem levar à descoberta de populações adicionais de $R$. bovallii, identificar áreas prioritárias de levantamento e, ao determinar a extensão de seu habitat natural, promover estratégias de conservação eficazes.
\end{abstract}

Palavras-chave: áreas centrais de habitat, distribuição disjunta, habitat marginal, modelos de distribuição de espécies.

\section{Introduction}

A complex interaction of biotic (e.g., sourcesink dynamics, habitat heterogeneity, competition, and mutualism), abiotic (e.g., climate, hydrologic and topographic changes), and evolutionary (e.g., speciation rates, extinction rates, and niche conservatism) processes have been suggested to play a key role in shaping Neotropical biodiversity (Van der Hammen and Hooghiemstra 2000, Antonelli and Sanmartín 2011, Antonelli et al. 2018). The Neotropical region (i.e., tropical America) is the most species-rich region on Earth and houses nearly a third of the world's biodiversity hotspots (Mittermeier et al. 2004). The Chocó Biogeographic Region (located within the Tumbes-Chocó-Magdalena hotspot, formerly called the Chocó-Darién-Western Ecuador hotspot) harbors an exceptional species richness and endemism in a relatively small area $(187,400$ $\mathrm{km}^{2}$, Mittermeier et al. 2004) less than $\sim 3 \%$ of the area of the Amazon Basin. For reptiles, especially snakes, the Chocó and Amazonian ecoregions have a close biogeographic affinity at the suprageneric-level, sharing about $55 \%$ of genera and $66 \%$ of families (data analyzed from Lynch et al. 2016). This fact suggests that these ecoregions had an ancient common history before the Andean uplift (between 2.7-5 Ma; Gregory-Wodzicki 2000), which may have resulted in allopatric speciation when populations of lowland species became isolated on either side of the cordillera (Hernández-Camacho et al. 1992, Smith et al. 2014, Winterton et al. 2014).

The two species of Rhinobothryum Wagler, 1830 may provide the clearest example of allopatric distributions among Neotropical snakes. The distributions of Rhinobothryum bovalli (Andersson, 1916) and Rhinobothryum lentiginosum (Scopoli, 1785) suggest the separation of a once-continuous range into two geographically isolated, or allopatric, parts (Rojas-Morales 2012). Rhinobothryum bovalli 
occurs in lowlands from southern Honduras to Costa Rica and Panama in Central America, and from western Colombia to northwestern Ecuador and northeastern Venezuela in South America (Savage 2002, Rojas-Morales 2012, McCranie 2015, Rojas-Runjaic and Infante-Rivero 2018, Turcios-Casco et al. 2018, Martínez-Fonseca et al. 2019). In contrast, $R$. lentiginosum occurs in lowlands along the Amazon Basin in South America, with records from Colombia, Ecuador, Peru, Bolivia, Paraguay, Brazil, French Guiana, Suriname, Guyana, and Venezuela (Peters and Orejas-Miranda 1970, Martins and Oliveira 1998, Miranda et al. 2009, Wallach et al. 2014, Gomes de Arruda et al. 2015). The geographic distributions of these species differ substantially; nevertheless, the limits of their ranges are uncertain. This is especially true of $R$. bovallii, a snake that is rarely seen and that apparently has disjunct distributions within its geographical range (Savage 2002, Wilson and McCranie 2003, Martínez-Fonseca et al. 2019).

Methods for estimating the distribution of a species based on fundamental ecological niche theory allow us to: (1) model the distribution of poorly known species (e.g., Raxworthy et al. 2003, Meza-Joya et al. 2018); (2) predict the potential geographic range of invasive species (e.g., Rödder and Lötters 2010, Urbina-Cardona and Castro 2010); (3) develop conservation action plans (e.g., Araújo et al. 2019, BoteroDelgadillo et al. 2012); (4) predict the effects of climate change on species distributions (e.g., Ochoa-Ochoa et al. 2012, Velásquez-Tibatá et al. 2013); (5) develop vector-borne disease spread and risk models (e.g., Peterson 2006, Fatima et al. 2016); and (5) identify historic refugia for biodiversity (e.g., Waltari et al. 2007, Vega et al. 2010). Species distribution models (SDMs) use predictor variables and species occurrences (either presence-only or presenceabsence) to estimate objects in geographic space, referring to the actual distribution of a given species (Peterson and Soberón 2012). However, predicting the distribution of rarer species is challenging because the factors that contribute to rarity (e.g., range size, habitat specificity, and local density) are poorly known for most taxa (Rabinowitz 1981, Karl et al. 2002, Franklin et al. 2009).

Rare species are highly sensitive to both natural and human-related disturbances, which increases their vulnerability, and therefore, their risk of extinction (Davies et al. 2004). Here we study the distribution of $R$. bovallii, a species that is rarely encountered and that apparently has a naturally disjunct distribution from lowest Central America to northwest South America (Savage 2002, Rojas-Morales 2012, McCranie 2015, Martínez-Fonseca et al. 2019). The rarity of this species has been attributed to sampling bias, low encounter rates, and the difficulty of sampling arboreal habitats (Arredondo et al. 2017, Rojas-Runjaic and Infante-Rivero 2018). Our primary objective was to update the distributional range of $R$. bovallii using reliable historical, as well as new records in conjunction with predictive species distribution models. We also assess the effect of predictor variables that have a major influence in shaping the current environmental niche of this species. Last, we identified areas where the predicted habitat suitability differs in order to identify core and marginal habitats for conservation purposes. Our results underscore the utility of predictive models in exploring the distribution of elusive and rare species.

\section{Materials and Methods}

\section{Species Data}

We compiled locality information for Rhinobothryum bovalli from museum specimens, well-supported reports from published literature, and records from our field surveys (collection permits 164-2014, 1166-2014 by Corporación Autónoma Regional de Caldas-Corpocaldas, and 0047-2015 by Autoridad Nacional de Licencias Ambientales-ANLA). We obtained additional data from the Global Biodiversity Information Facility (http://www.gbif.org), the VertNet data 
portal (http://www.vertnet.org), and SiB Colombia (http://www.sibcolombia.net) accessed on 20 October 2019. Our analyses only include wellsupported records from these electronic databases because they are prone to contain inaccuracies (Nogueira et al. 2011, Zaher et al. 2011). The accuracy of an occurrence record was considered reliable if: (1) it was published by a reliable source (e.g., herpetological collection or museum); (2) it was supported by a voucher specimen; and (3) its taxonomic diagnose was confirmed by a curator or previous studies. We also included photographic records from http://www.inaturalist. org because this snake is very conspicuous and easily recognized by photographs. Each record available was checked to identify uncertainty and mistakes in the geographic information. We retained localities with geographic coordinates assigned by other authors based on collection locality data (Appendix I). Although there is uncertainty associated with these coordinates, we expect them to fall near or in the correct pixel of the environmental data (pixel size is 30 arc-seconds or about $1 \mathrm{~km}^{2}$ ). We excluded records with incomplete, inconsistent, or imprecise geographic information.

\section{Environmental Data}

To explore predictors that are likely to affect the distributions of species, we used climatic data from 19 WorldClim variables and elevation (Hijmans et al. 2005) at a 30 arc-seconds spatial resolution (ca. $1 \mathrm{~km}^{2}$ ). We restricted the selection of environmental data from "background" pixels to a region that matched areas from which of Rhinobothryum bovalli is known to occur and thus, might be representative of suitable environmental conditions for the species (Anderson and Raza 2010, Peterson et al. 2011, Galante et al. 2018). We used a rectangle encompassing a four-degree buffer (ca. 450 linear $\mathrm{km}$ ) around the most extreme locality at each cardinal direction. This selection method seems appropriate because it excludes large areas that are environmentally suitable, but where the species is likely unable to disperse-because of the presence of insurmountable physical or physiological barriers to dispersal-and/or is not known to occur (i.e., geographic areas where the species has not been reported or collected historically or inventory pseudo-absences).

\section{Sampling Bias}

To reduce the likely effects of spatial autocorrelation in our initial occurrence dataset ( $N=103$ unique localities), we used SDMtoolbox to filter localities keeping the maximum number of occurrences that were at least $20 \mathrm{~km}$ apart (Brown et al. 2017). This distance threshold was selected because Rhinobothryum bovalli is distributed mainly in lowlands, which are expected to have low levels of topographic heterogeneity. This procedure produced a maximum number of 65 points of occurrence. To address possible sensitivity of this procedure in resulting models (Galante et al. 2018), we first ran a series of starting models with the unfiltered dataset and then with the spatially filtered one. To build these models, we used the recommended feature classes to be appropriate for our sample sizes-all feature classes for the unfiltered dataset and linear plus quadratic plus hinge for the filtered one (Phillips and Dudík 2008). For each feature class combination, we used a narrow range of regularization multiplier values close to the default value-i.e., 0.5, 1 (default value), 1.5, and 2. Regularization was employed to reduce the number of variables selected for inclusion in the resulting models (Phillips and Dudík 2008, Elith et al. 2011). We used the occurrence dataset from the best-ranked model (i.e., unfiltered dataset) to build the suite of final candidate models.

\section{Variable Reduction}

To ensure the quality of the final suite of habitat suitability models and to reduce potential over-parameterization, we followed 
the process outlined by Warren et al. (2014). For this, we calculated the contribution scores (permutation importance and percentage contribution) for each variable in our suite of starting models (see above). To obtain alternate estimates of which variables are most important in the model, we also ran a jackknife test. Then, we calculated the spatial correlations (Pearson coefficient) between variables using the software ENMTools version 1.4.4 (Warren et al. 2010). We used contribution scores in conjunction with the scores from correlations to select the final set of environmental variables. First, we eliminated variables with low contribution scores $(<5 \%)$ in the starting model. Then, we deleted variables that were highly correlated $(|r|>0.85)$ following Elith et al. (2010), keeping the variables with the highest contribution scores. We extracted from the best-ranked model the reduced set of variables to build the suite of final candidate models.

\section{Species Distribution Modelling}

We generated SDMs using MaxEnt version 3.4.1, a presence-background algorithm that integrates environmental data with georeferenced occurrence records to model the habitat suitability of a given species (Phillips et al. 2006). Although many methods are available for modeling distributions, MaxEnt has high predictive accuracy for a wide range of species in diverse regions, even when available information is incomplete and the sample size is small (e.g., Pearson et al. 2007, Anderson and Raza 2010, Chunco et al. 2013, Ramos et al. 2018). We used recommended default values for convergence threshold $\left(10^{-5}\right)$, maximum number of iterations (500), maximum number of background points $\left(10^{4}\right)$, and default prevalence of the species (0.5). Last, we selected the logistic output format, which yields continuous values ranging from 0 to 1 that indicate the probability of suitable environmental conditions for the species (Phillips and Dudík 2008). We built final candidate models randomly excluding $30 \%$ of the observation records to use as test data, with 100 bootstrapped replicates.

\section{Model Calibration}

Final candidate models were generated using multiple combinations of distinct values of regularization multipliers and feature classes to identify the parameter settings that lead to best-fitting models. These models were built using unfiltered occurrence (Table 1) and withheld environmental data (Table 2). We created a suite of models by allowing increasing complexity of the feature classes employed, taking into account our sample size (i.e., 103 occurrence points; see Phillips and Dudík 2008, Elith et al. 2011): hinge (H), linear plus quadratic (LQ), linear plus quadratic plus hinge (LQH), and all features (default setting). For each feature class combination, we built models using the same range of regularization multiplier values as in starting models (i.e., 0.5, 1, 1.5, and 2).

Table 1. Summary of evaluation statistics of the starting models for Rhinobothryum bovallii. Results are provided for two model-selection techniques (AUC and OR) for two datasets (unfiltered and filtered localities) using recommended features classes (all features and linear plus quadratic plus hinge, respectively). Omission rates (OR) based on the minimum training presence threshold.

\begin{tabular}{lccc}
\hline Feature & Regularization & OR & AUC \\
\hline Unfiltered & 0.5 & 0.037 & 0.954 \\
(103 & 1 & 0.013 & 0.941 \\
& 1.5 & 0.023 & 0.933 \\
Filtered & 2 & 0.031 & 0.912 \\
(65 & 0.5 & 0.085 & 0.962 \\
occurrences) & 1 & 0.057 & 0.933 \\
& 1.5 & 0.061 & 0.921 \\
& 2 & 0.029 & 0.893 \\
\hline
\end{tabular}


Table 2. Percentage of contribution and permutation importance of the most important variables used to build final species distribution models for Rhinobothryum bovallii. The four variables with the highest contributions are presented in bold.

\begin{tabular}{lccc}
\hline Variable & Code & Permutation importance & Percent contribution \\
\hline Precipitation seasonality & $\mathrm{BIO} 15$ & $\mathbf{2 5}$ & $\mathbf{1 6}$ \\
Precipitation of warmest quarter & $\mathrm{BIO} 18$ & $\mathbf{7 . 4}$ & $\mathbf{1 4 . 7}$ \\
Elevation & - & $\mathbf{1 0 . 6}$ & $\mathbf{1 4 . 1}$ \\
Precipitation of driest quarter & $\mathrm{BIO} 17$ & $\mathbf{6 . 9}$ & 2 \\
Temperature annual range & $\mathrm{BIO7}$ & 5.1 & $\mathbf{1 3 . 4}$ \\
\hline
\end{tabular}

\section{Model Selection}

We compared all the models generated by using the scores of two quantitative measures: (1) area under a receiver operating characteristic curve (AUC; threshold-independent), and (2) omission rate by applying the minimum training presence threshold (OR; threshold-dependent). Specifically, the AUC gives a relative measure of the overall discriminatory ability of a model (Peterson et al. 2011), whereas omission rates indicate whether a model is overfitted to the calibration data (Galante et al. 2018). By using this threshold rule, we expect $0 \%$ test omission; thus, values above zero indicate overfitting (Shcheglovitova and Anderson 2013). Hence, we used OR as the primary criterion for selecting optimal combinations of feature classes and regularization multiplier (Shcheglovitova and Anderson 2013). We first identified the models that displayed the lowest average OR, and then, from that subset of models, we chose the one with the highest average AUC score.

\section{Binary Model and Core Areas}

Once we selected the best-ranked model, its logistic output was transformed into a binary prediction model for the suitable habitat of the species (i.e., a presence/absence map) by applying the minimum training presence threshold value for the training occurrence data obtained by MaxEnt. This threshold rule was chosen because it has a straightforward ecological interpretation by identifying pixels predicted to be at least as suitable as those from which the species has been recorded (Pearson et al. 2007). Then, we evaluated the final binary model by visual examination based on our knowledge of the natural history and geographic distribution of Rhinobothryum bovalli. To identify core habitats, we follow the approach proposed by Molloy et al. (2014). We converted predictions of the bestranked model by applying the threshold cut-off training value for the 10-percentile training presence threshold. This approach seems rational because the threshold rule excludes all regions having suitability values lower than those for the lowest $10 \%$ of occurrence records (Radosavljevic and Anderson 2014) and leads to a smaller geographical prediction of high-quality habitats in environmental terms. Following this approach, areas with environmental values containing $90 \%$ of occurrence records were designated as core habitats (i.e., pixels of the model in which test occurrence points had a high probability of falling and where the species is most likely to sustain viable populations), whereas the remaining areas correspond to marginal habitats (i.e., pixels of the model representing a marginal part of the fundamental niche of the species in which survival and reproduction are thought to be poor because of the limiting environmental conditions). 


\section{Results}

\section{Models Performance}

In the starting models, the AUC values were slightly better for the models with the unfiltered dataset than those for models with filtered one (except for models calibrated to 0.5 regularization value). As expected, starting models of both datasets (spatially unfiltered and filtered) had OR values above the expected $0 \%$ for the minimum training presence threshold. However, starting models calibrated using the unfiltered dataset and all feature classes [as recommended by Phillips and Dudík (2008) for sample sizes $>80$ occurrence points] produced higher average evaluation scores (mean AUC $=0.935 \pm 0.018$ ) and lower average omission rates $(0.026 \pm 0.010)$ across regularization multipliers. Although the used of filtered occurrence results in the model with the highest AUC score (AUC $=0.962)$, its OR was six times greater $(\mathrm{OR}=0.085)$ than the model with the lowest one $(\mathrm{OR}=0.013)$, indicating greater overfitting in the first. The model performance measures (AUC and OR) of the suites of starting models are given in Table 1.

Observed average AUCs for our final models varied, with lower regularization multipliers leading to higher AUCs within a given feature class (Figure 1A). Default features (i.e., all features) displayed the highest average AUC values across regularization multipliers (mean $\mathrm{AUC}=0.930 \pm 0.019$ ), followed by LQH (mean $\mathrm{AUC}=0.922 \pm 0.021), \mathrm{H}($ mean $\mathrm{AUC}=0.920 \pm$ 0.018 ), and LQ features (mean AUC $=0.863 \pm$ 0.009; Figure 1B). The highest AUC value was observed for default features at the lowest regularization multiplier $(\mathrm{AUC}=0.950 \pm 0.007)$. However, the difference between this value and that for $\mathrm{LQH}$ and $\mathrm{H}$ features at the same regularization multiplier (i.e., 0.5) was minimal (0.004 for LQH and 0.006 for $\mathrm{H}$ features; Figure 1A).

Model calibration showed great differences in average ORs among feature classes, with LQH and LQ features obtaining the lowest OR values at low regularization multipliers and then dropping in performance at high regularization multiplier values. In contrast, default and $\mathrm{H}$ features showed the opposite pattern (Figure 1C). Linear plus quadratic plus hinge features displayed the lowest average OR values across regularization multipliers (mean $\mathrm{OR}=0.012 \pm$ 0.009 ), followed by LH (mean AUC $=0.014 \pm$ 0.008 ), default (mean AUC $=0.035 \pm 0.010$ ), and $\mathrm{H}$ features (mean AUC $=0.038 \pm 0.010$; Figure 1D). The lowest OR value was observed for the LQH feature at the lowest regularization multiplier $(\mathrm{OR}=0.000)$, which fix to the theoretical expectation of zero omission of evaluation localities using the minimum training presence threshold (Figure 1B).

Based on the criteria employed, the default settings (i.e., all feature classes and regularization multiplier of 1) were not optimal for our dataset. We identified the $\mathrm{LQH}$ feature class and the lowest examined regularization multiplier (i.e., 0.5 ) as the optimal combination for our datasets. Given the sequential nature of the selection criteria used here, we did not necessarily select the combination with the highest evaluation AUC as optimal. However, the difference between the AUC of the optimal combination (i.e., $\mathrm{LQH}$ features and regularization multiplier of 0.5 ) and that of the combination with the highest AUC (i.e., default features and regularization multiplier of 0.5 ) was negligible (AUC difference of 0.004). The model performance measures (AUC and OR) of the suites of final models are given in Figure 1.

\section{Variable Contribution and Response Curves}

The analysis of variable contributions reveals that precipitation seasonality, precipitation of warmest quarter, elevation, precipitation of driest quarter, and temperature annual range, significantly affect the distribution of Rhinobothryum bovalli (Table 2). Based on both metrics (i.e., permutation importance and percent contribution), precipitation seasonality has the greatest influence on the distribution of this 

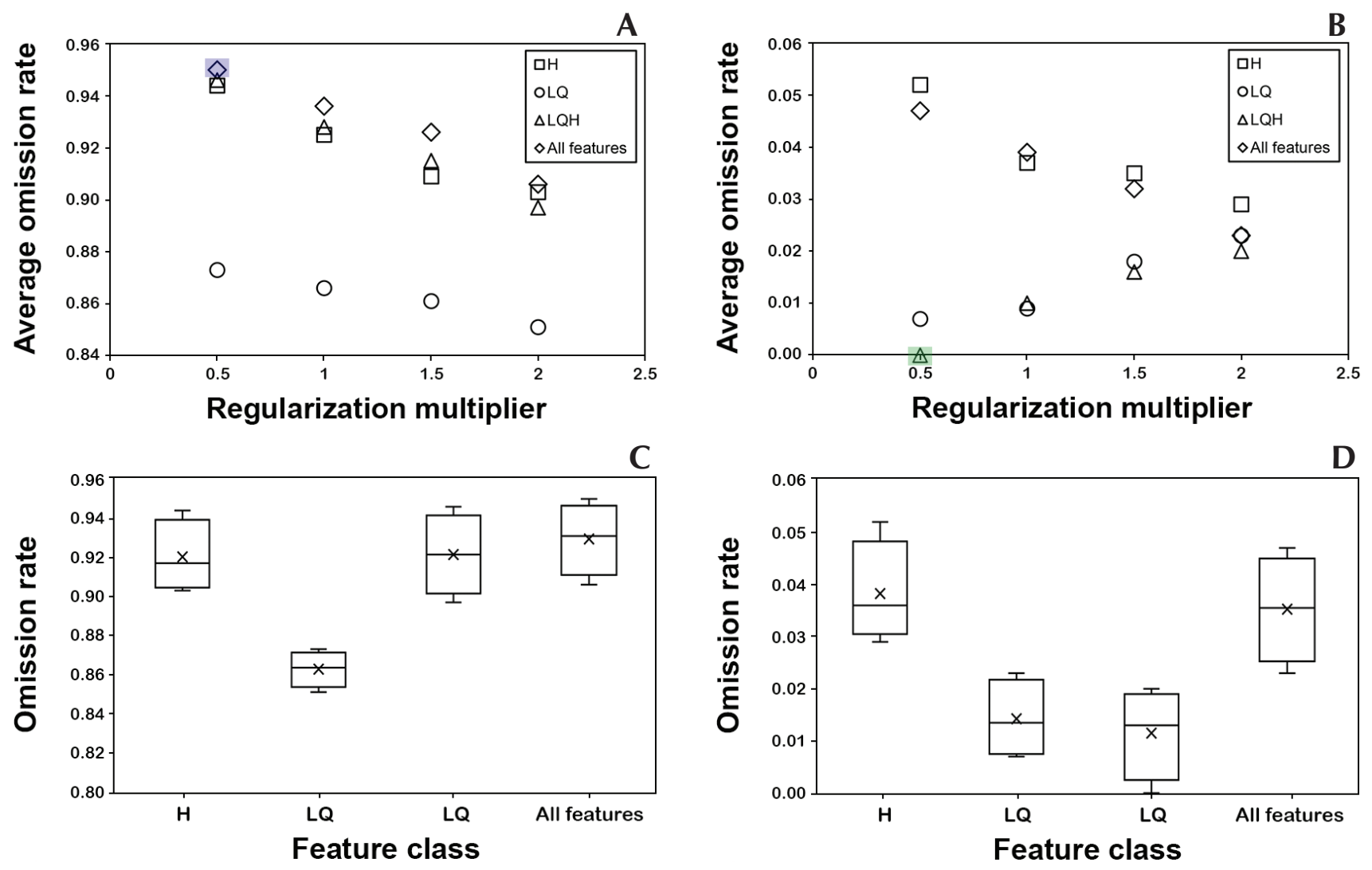

Figure 1. Evaluation statistics resulting from calibration of Maxent models for Rhinobothryum bovallii. Top panels show the test Area Under the Curve (AUC) scores (A) and the omission rates (OR) at minimum training presence threshold (B). Bottom panels show the statistics (i.e., median, first and third quartiles, minimum, and maximum) for AUC (C) and ORs (D) values compared across regularization multipliers for each feature class. In each panel, the optimal model is highlighted. Model statistics are shown as feature classes $(H=$ hinge, $L Q=$ linear plus quadratic, $L Q H=$ linear plus quadratic plus hinge, and all features) increasing in regularization multiplier (i.e., $0.5,1,1.5$, and 2 ).

species $(25 \%$ and $16 \%$, respectively). The jackknife test of variable importance shows that the environmental variable with the highest gain when used in isolation is temperature annual range-therefore contains the most useful information by itself, whereas precipitation seasonality decreases the gain the most when it is omitted-and thus contains information not present in any other variable (Figure 2). Response curves show that suitability was positively linked with low values of precipitation seasonality $(<$ $30 \%)$. Suitability was also maximized around $500 \mathrm{~mm}$ of precipitation in the warmest quarter and a temperature annual range of about $12^{\circ} \mathrm{C}$.
As expected, presence probability is highest at low elevations and decreases at higher altitudes (> $1000 \mathrm{~m}$ a.s.l.).

\section{Species Distribution Range}

To generate SDMs, we compiled 103 reliable locality records for Rhinobothryum bovalli (84 historical and 19 new). Known records of this species range from about $0^{\circ}$ to $15^{\circ} \mathrm{N}$ latitude, with the archaeological site "Ciudad Blanca" in Honduras and the Caique River in Ecuador, the northernmost and southernmost known localities, respectively (Pazmiño-Otamendi 2017, Turcios- 


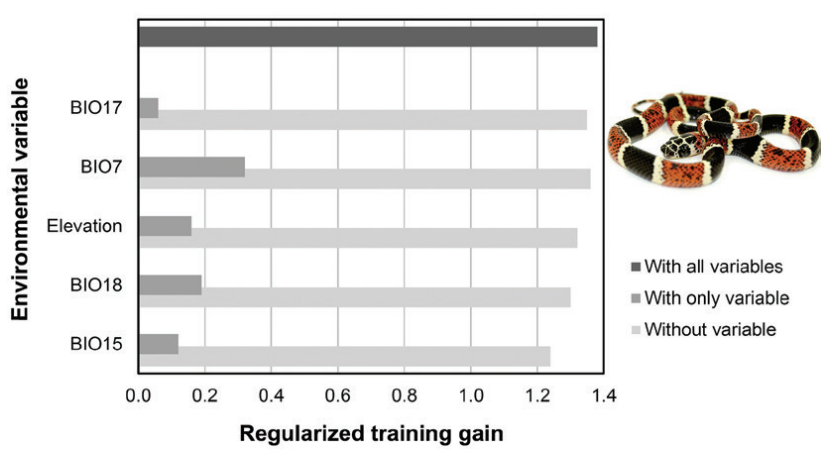

Figure 2. Jackknife test of variable importance showing regularized training gain of individual predictor variables important in the development of final models for Rhinobothryum bovallii.

Casco et al. 2018). Records come from 12 of the ecoregions proposed by Dinerstein et al. (2017): Central American Atlantic moist forests, Talamancan montane forests, Isthmian-Atlantic moist forests, Isthmian-Pacific moist forests, Chocó-Darién moist forests, Western Ecuador moist forests, Cauca Valley montane forests, Magdalena Valley montane forests, MagdalenaUrabá moist forests, Magdalena Valley dry forests, Sinú Valley dry forests, and Cordillera Oriental montane forests. Review of digital photographs of a specimen of $R$. bovallii from Caquetá department (Solano municipality) on the Amazon versant of Colombia (IAvH-R 6453, IAvH-R 6454 in Martínez-Fonseca et al. 2019) confirm that it is $R$. lentiginosum. Examination of a specimen from the same locality deposited at Universidad de la Amazonia in Colombia (UAM-R uncatalogued) supports this determination. Specimens of $R$. bovallii from Suriname and Guyana (see http://vertnet.org) probably correspond to misidentifications of the congeneric species $R$. lentiginosum (see also Martínez-Fonseca et al. 2019). Based on geographic coordinates of locality records (Appendix I), the altitudinal range for $R$. bovallii ranges from sea level (QCAZ-R 4652) to 1535 m (KU 75749). The updated distribution of $R$. bovallii is summarized in Figure 3A (For additional details, see Appendix I).
The logistic output of the best-ranked model identified several regions of high prediction for $R$. bovalli in most parts of the Caribbean coast of southern Nicaragua, Costa Rica, and Panama; tenuously connected areas of the Chocó region in Panama, Colombia, and Ecuador; Middle Magdalena Valley in Colombia; and isolated portions of the Caribbean regions in Colombia and Venezuela. Furthermore, the model identified small, isolated areas of high suitability in regions from which there are no records for the species. These areas include the eastern slope of the Cordillera Oriental, the upper basin of the Magdalena River, and the Catatumbo Basin in Colombia, as well as the Machango, Misoa, and Rio Viejo basins in Venezuela, all of which drain to the east of the Maracaibo Lake. South of this area, the model predicts the potential presence of $R$. bovalli in the foothills of the Merida Cordillera (Figure 3B). According to the binary map generated using the cut-off training value for the minimum training presence threshold (i.e., 0.424), we estimated an extent of occurrence of $491,516 \mathrm{~km}^{2}$ for the species (Figure 4A). After applying the cut-off value for the 10-percentile training presence threshold (i.e., 0.396) we identify three main core habitat areas, summing approximately $59,353 \mathrm{~km}^{2}$ (Figure 4B): a "northern core" along the Pacific and Caribbean coasts of Panama $\left(\sim 31,529 \mathrm{~km}^{2}\right)$; a "central core" in the Middle Magdalena Valley in Colombia ( 20,939 $\left.\mathrm{km}^{2}\right)$; and a "southern core" in the Ecuadorian Chocó $\left(\sim 6,885 \mathrm{~km}^{2}\right)$.

\section{Discussion}

\section{Models Performance}

The starting models using unfiltered versus filtered datasets yielded substantially higher OR values when the minimum training presence threshold was applied to both datasets. However, the unfiltered dataset leads to models with higher AUC scores and lower ORs across regularization multipliers. Use of the unfiltered dataset led to models with areas of higher prediction 

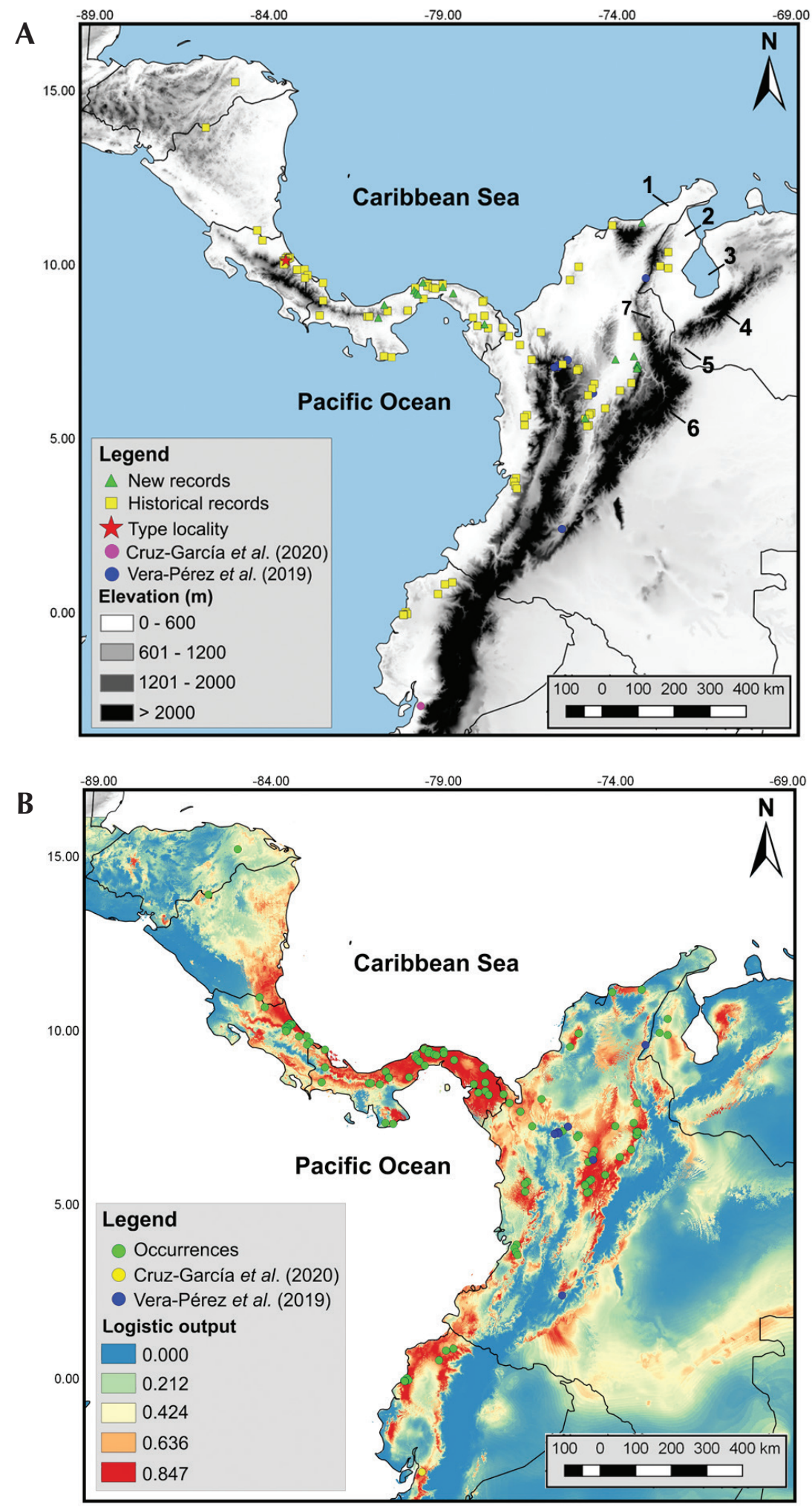

Figure 3. Updated distributional map (A) and logistic output for the best-ranked model (B) for Rhinobothryum bovallii. Map numbers indicate: 1 = Guajira-Barranquilla xeric scrub ecoregion (Colombia), 2 = Paraguaná xeric scrubs ecoregion (Venezuela), 3 = Maracaibo Lake (Venezuela), 4 = Cordillera de Mérida (Venezuela), $5=$ Táchira depression (Venezuela), 6 = Cordillera Oriental (Colombia), 7 = Catatumbo basin (Colombia). Geodetic datum = WGS-84. 

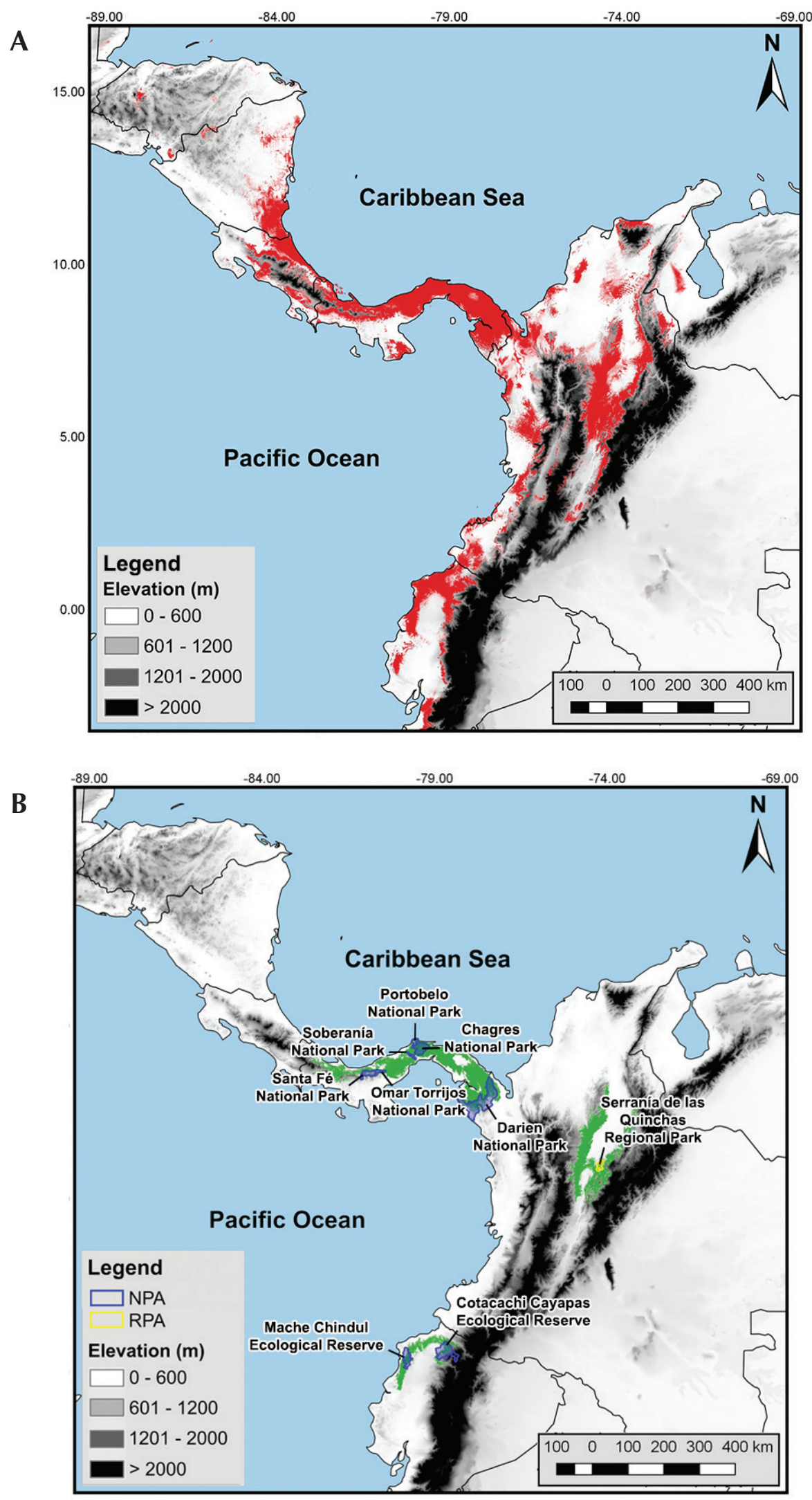

Figure 4. Binary distribution map (A) and main core habitat areas (B) for Rhinobothryum bovallii. NPA = National protected areas. RPA $=$ Regional protected areas. Geodetic datum $=$ WGS-84. 
concentrated around known records, suggesting low sampling bias, as well as more realistic geographic predictions, in contrast to the filtered dataset. Although spatially filtered data is most likely to match the assumption of unbiased sampling (Galante et al. 2018), it is probable that the rarity of Rhinobothryum bovalli throughout its range may contribute to reduced sampling bias in our unfiltered dataset, and as a consequence, to best geographic predictions. Although the unfiltered dataset used here seems to be minimally affected by bias problems, it is critical to conduct filtering analysis to assess whether the resulting models are affected by spatial sampling bias (Radosavljevic and Anderson 2014, Boria et al. 2014, Galante et al. 2018).

In the model calibration, lower regularization multipliers lead to higher AUC values within a given feature class. Although OR scores were variable across the feature classes, low regularization multipliers $(0.5)$ were necessary to reduce overfitting to the lowest levels (Figure 1). Although the highest point in AUC occurs when default features (i.e., all features) are used, ORs indicate much better performance with LQH features. The fact that optimal performance corresponds to more complex sets of feature classes supports the findings of previous studies (e.g., Shcheglovitova and Anderson 2013, Galante et al. 2018, Ramos et al. 2018). Notably, these studies examined species with few occurrence records ( $<23$ localities), whereas $R$. bovalli has 103 occurrence points. Thus, our finding that overfitting decreases at regularization multipliers lower than default when used with more complex sets of feature classes contrasts with the results from other studies using both small ( $<23$ localities) and large ( $>208$ localities) datasets (e.g., Shcheglovitova and Anderson 2013, Radosavljevic and Anderson 2014, Ramos et al. 2018). While low regularization values tend to result in overly complex models (Radosavljevic and Anderson 2014), it is probable that the removal of highly correlated variables in our study provides additional protection against overfitting that leads to low regularization scores and an increase in performance.

\section{Variable Contribution and Response Curves}

The predicted habitat suitability for Rhinobothryum bovalli in environmental space is represented by low variability of monthly precipitation values during the year (i.e., precipitation seasonality), high values of precipitation during the warmest three months of the year (i.e., precipitation in the warmest quarter), and low variability in annual temperature (i.e., temperature annual range). In general, these results show that climatic habitat suitability for this species is highest in most equatorial regions and decreases toward more northerly and southern latitudes. Areas with high habitat suitability coincide largely with tropical moist forests, which are characterized by high levels of rainfall and low variability in annual temperature (Rangel-Ch and Arellano-P 2004). Chocó-Darién moist forests, Northern Andean montane forest, and Isthmian-Atlantic moist forests are the best-represented ecoregions in the distribution of this species. In addition, our model produced low habitat suitability scores for higher elevations (i.e., above $~ 1000 \mathrm{~m}$ a.s.l.) in the Andes of northern South America and the mountain ranges of Central America (Figure 3B). The effect of elevation on species distributions is realized by changes in ecological variables, such as temperature, rainfall, and solar radiation (Elith and Leathwick 2009) that determine vegetation structure and habitat quality (Pokharel et al. 2016). Investigation of the point at which environmental variables diverge to distinguish core versus marginal habitats may result in a better understanding of conditions that favor adaptation to lower-quality habitats.

\section{Species Distribution Range}

The geographic information presented here indicates that the distribution of Rhinobothryum bovalli is a disjunct within its range between the 
Central American Isthmus and the northwestern portion of South America, where the snake occupies lowlands and premontane forests below $\sim 1500 \mathrm{~m}$ elevation (Figure 3A; Appendix I). The most eastern reported localities for $R$. bovalli lie on the eastern flank of the Serranía del Perijá (or Sierra de Perijá) in Venezuela (Figure 3A; Rojas-Runjaic and Infante-Rivero 2018). Although the species has been reported to occur in moist forest on the western slope of the Cordillera Oriental, inter-Andean Valleys, and Sierra Nevada de Santa Marta in Colombia (Figure 3A), its presence in the Venezuelan Sierra de Perijá is unanticipated because there is no known basimontane moist corridor along which the species could disperse. However, $R$. bovalli might have colonized the area during the Pliocene ( 3.30 Mya) prior to an intense global glaciation that occurred after the major known Andean uplift (2000-3000 m a.s.1.) at the end of this period (Lazala 2007). Validation of this hypothesis would require a dated phylogeny for snakes that includes several populations of both species of Rhinobothryum.

Our distribution model includes small areas of high probability of occurrence east of the Andes. Included are the eastern slope of the Cordillera Oriental in Colombia (with the Catatumbo Basin), as well as areas around the Maracaibo Lake and the foothills of the Cordillera de Mérida in Venezuela (Figure 4A). Given that the potential habitat for $R$. bovalli is characterized by low seasonal precipitation, high precipitation in the warmest quarter, and low variability in annual temperature (Table 2, Figure 2 ), it is logical to suppose that arid and semiarid conditions would restrict the distribution of this snake. Therefore, xeric areas in the GuajiraBarranquilla and Paraguaná xeric scrubs ecoregions (Dinerstein et al. 2017) and semiarid areas of the Táchira Depression (La Marca 1997) may represent environmental barriers limiting the distribution of this species south Cordillera de Mérida. Unexplored or under-sampled areas must be surveyed to generate more robust SDMs for $R$. bovalli.
Two studies reporting new locality records for $R$. bovalli were published recently_including the first record from the Colombian slope of the Serranía del Perijá (Vera-Pérez et al. 2019) and the second from Ecuador (Cruz-García et al. 2020) (Figure 3A, Appendix I). These appeared coincident with the submission of this manuscript for publication; thus, neither was included in our species distribution modeling. However, these records coincide with areas of high habitat suitability predicted by our models, especially the noteworthy records from the upper Magdalena Valley (Huila Department) and Serranía del Perijá (Cesar Department) in Colombia, and the southernmost record from Guayas province in Ecuador (Figure 3B). This suggests that our models have a high predictive performance and underscores the importance of this methodological approach for making predictions about the distribution of elusive and rare species (Raxworthy et al. 2003, Pearson et al. 2007, Anderson and Raza 2010, Chunco et al. 2013). Last, it is important to note that other factors not incorporated in our models (e.g., land-cover change and interspecies interactions) also may limit the presence of this species in otherwise suitable areas.

\section{Historical Biogeography}

The phylogenetic relationships of Neotropical colubrids are unresolved. However, recent studies suggest that Rhinobothryum may be closely related to Nearctic colubrids such as Drymarchon, Drymoluber, Mastigodryas, and Palusophis (Montingelli et al. 2019, Zaher et al. 2019), with the divergence between Rhinobothryum and the clade formed by Drymoluber, Mastigodryas, and Palusophis occurring in the middle Miocene, at 16 Mya (Zaher et al. 2019). These results support Duellman's proposal (1990) that the Rhinobothryum clade is old and originated in the north long before the lineage arrived in South America shortly after the final closure of the Isthmus of Panama during the Pliocene, at $~ 3.5-$ 4.5 Mya. The allopatric ranges of current species 
of Rhinobothryum are separated by major Andean mountain ranges, thereby suggesting an ancestral vicariance event (Rojas-Morales 2012). Our models indicate small areas of high habitat suitability for $R$. bovalli in the southeastern foothills of the Cordillera Oriental in Colombia (Figure 4A). This region represents an AndesAmazon-Orinoquia transition area, where biotic elements of these three large units converge (Hernández-Camacho and Sánchez 1992). Although this area contains pixels of high environmental suitability, it is unlikely that $R$. bovalli occurs there because environmental barriers would limit the distribution of the species south Cordillera de Mérida (discussed above).

It is improbable that an area of sympatry exists between the two species of Rhinobothryum, owing to the presence of environmental and topographical barriers limiting their distributions. Pliocene uplift events (i.e., final uplift of the Northern Andes and Huancabamba Depression) may have promoted the divergence between $R$. bovallii and $R$. lentiginosum by isolating eastern from western populations of the genus (RojasMorales 2012). The most western known locality for R. lentiginosum in Colombia is Araracuara (Solano municipality) at the Caquetá River (IAvH-R 6453-54) - this site is about $400 \mathrm{~km}$ (airline) from the Cordillera Oriental in Colombia. This distance suggests that there may be additional dispersal barriers, such as Amazonian rivers that are thought to have played a key role as barriers to dispersal and prompting diversification and speciation events (Pomara et al. 2014). Moreover, expansion and retraction of dry tropical forest and grassland habitats in the Amazon and Orinoco basins since the Last Glacial Maximum (Anhuf et al. 2006) also might promote diversification.

\section{Implications for Conservation}

Species conservation often must be prioritized to achieve the best outcomes from the resources invested (Hughey et al. 2003). Core areas are a priority for the conservation of Rhinobothryum bovalli, because these areas possess a unique combination of environmental features that is likely to ensure the survival and maintenance of viable populations through time. Relative to the predicted range of $R$. bovalli (i.e., $491,516 \mathrm{~km}^{2}$ ), the sum of its core areas is minimal $(59,353$ $\mathrm{km}^{2}$ ), and the cores are fragmented and relatively isolated from one another (Figure 4B). These areas largely coincide with lowland (below $500 \mathrm{~m}$ a.s.1.) tropical moist forests, which represent primary habitat for this species. Core areas in Panama and Ecuador coincide with more extensive and least-fragmented forest, and they also possess an important number of national protected areas with strict categories of management (Category I and II sensu Dudley 2008)_viz., six National Parks in Panama and two Ecological Reserves in Ecuador. In contrast, the core area in Colombia coincides with areas suffering extensive deforestation primarily resulting from commercial agriculture, cattle ranching, hydroelectric generation, and extractive industry (Garzón and Gutiérrez 2013, Fagua et al. 2019); only a regional protected area for strict conservation exists in this region-Serranía de Las Quinchas Regional Natural Park (Figure 4B).

As for many other species, the range of $R$. bovalli comprises a few, large core habitats surrounded by numerous, smaller marginal ones. However, these peripheral populations differ from those inhabiting core areas because often they are patchily distributed, less dense, more isolated, and subject to limited resources and greater environmental variability, all of which contributes to their risk of extinction (Eckert et al. 2008, Hardie and Hutchings 2010, Peterman et al. 2013). We do not favor the conservation of marginal habitats at the expense of core ones, but we do think it is crucial to determine which marginal habitats are likely to be most important for conservation purposes, and protect them before they are lost (e.g., those inhabited by populations with high evolutionary potential or/ and acting as links between existing metapopulations). From a conservation perspective, key areas that can ensure the long-term viability of 
populations (e.g., priority habitats within core areas) and connectivity (e.g., marginal "stepping stone" areas connecting metapopulations) should be protected.

\section{Acknowledgments}

We are indebted to Juliett González and Sofia Fajardo, who allowed us to use their unpublished locality records for Rhinobothryum bovalli. Angel Sosa and Roberto Ibáñez kindly provided unpublished data for specimens in herpetological collections in Panama. The following curators and associated museum personnel kindly make available to us photographs of specimens under their care: Andrés Acosta (IAvH) and Fabián Cabrera (UAM). Manfredo Turcios-Casco assisted us in georeferencing records from Honduras. The manuscript was improved by comments from Fernando Rojas-Runjaic and two anonymous reviewers.

\section{References}

Acosta-Galvis, A. and K. Borja-Acosta (eds.). 2018. Anfibios y reptiles del municipio El Carmen de Chucurí, Santander - Proyecto Santander BIO. Version 3.1. Electronic Database accessible at https://doi. org/10.15472/rlwmxs/ Instituto de Investigación de Recursos Biológicos Alexander von Humboldt, Villa de Leyva, Colombia. Captured on 11 June 2019.

Andersson, L. G. 1916. Notes on the reptiles and batrachians in the Zoological Museum at Gothenburg with an account of some new species. Göteborgs Kungliga Vetenskap och Vitter Hets-Samnalles Hndlingar Sjatte Foljden 17: 1-41.

Anderson, R. P. and A. Raza. 2010. The effect of the extent of the study region on GIS models of species geographic distributions and estimates of niche evolution: preliminary tests with montane rodents (genus Nephelomys) in Venezuela. Journal of Biogeography 37: 1378-1393.

Anhuf, D., M. P. Ledru, H. Behling, F. W. Jr. da Cruz, R. C. Cordeiro, T. Van der Hammen, I. Karmann, J. A. Marengo, P. E. de Oliveira, L. Pessenda, A. Siffedine, A. L. Albuquerque, and P. L. da Silva. 2006. Paleoenvironmental change in Amazonian and African rainforest during the LGM. Palaeogeography, Palaeoclimatology, Palaeoecology 239: 510-527.
Antonelli, A. and I. Sanmartín. 2011. Why are there so many plant species in the Neotropics? Taxon 60: 403-414.

Antonelli, A., A. Zizka, F. A. Carvalho, R. Scharn, C. D. Bacon, D. Silvestro, and F. L. Condamine. 2018. Amazonia is the primary source of Neotropical biodiversity. Proceedings of the National Academy of Sciences 115: 6034-6039.

Araújo, M. B., R. P. Anderson, A. M. Barbosa, C. M. Beale, C. F. Dormann, R. Early, R. A. Garcia, A. Guisan, L. Maiorano, B. Naimi, R. B. O'Hara, N. E. Zimmermann, and C. Rahbek. 2019. Standards for distribution models in biodiversity assessments. Science Advances 5: eaat 4858 .

Arredondo, J. C., D. F. Cisneros-Heredia, G. Rivas, J. Sunyer, and J. H. Townsend. 2017. Rhinobothryum bovallii. The IUCN Red List of Threatened Species. Version 2019-3. Electronic Database accessible at https://www.iucnredlist.org. Captured on 11 June 2019.

Barreto-Martínez, A. J. and J. A. Rojas-Morales. 2020. A Clutch of the False Tree Coral, Rhinobothryum bovallii Anderson 1916 (Squamata: Colubridae), in the Colombian Caribbean. IRCF Reptiles \& Amphibians 27: 46-47.

Boria, R. A., L. E. Olson, S. M. Goodman, and R. P. Anderson. 2014. Spatial filtering to reduce sampling bias can improve the performance of ecological niche models. Ecological Modelling 275: 73-77.

Borja-Acosta, K. (ed.). 2017. Colección de Reptiles del Instituto Alexander von Humboldt. Version 23.0. Electronic Database accessible at https://doi.org/ 10.15472/bg0gnd/ Instituto de Investigación de Recursos Biológicos Alexander von Humboldt, Villa de Leyva, Colombia. Captured on 11 June 2019.

Botero-Delgadillo, E., C. A. Páez, and N. Bayly. 2012. Biogeography and conservation of Andean and TransAndean populations of Pyrrhura parakeets in Colombia: modelling geographic distributions to identify independent conservation units. Bird Conservation International 22: 445-461.

Brown, J. L., J. R. Bennett, and C. M. French. 2017. SDMtoolbox 2.0: the next generation Python-based GIS toolkit for landscape genetic, biogeographic and species distribution model analyses. PeerJ 5: e4095.

Brown, R. (ed.). 2018. KUBI Herpetology Collection. Version 31.18. Electronic Database accessible at https:// doi.org/10.15468/ubdwdc/ University of Kansas Biodiversity Institute, Lawrence, USA. Captured on 11 June 2019.

Cadle, J. E. 2012. Cryptic species within the Dendrophidion vinitor complex in Middle America (Serpentes: Colubridae). Bulletin of the Museum of Comparative Zoology 160: $183-240$. 
Campbell, H. W. and T. R. Howell. 1965. Herpetological records from Nicaragua. Herpetologica 21: 130-140.

Carrizo, A. R. 2010. Riqueza y abundancia de la herpetofauna de la Cuenca Alta del río Santa María, Santa Fe, Veraguas. Unpublished M.Sc. Dissertation, Universidad Autónoma de Chiriquí, Panama.

Chunco, A. J., S. Phimmachak, N. Sivongxay, and B. L. Stuart. 2013. Predicting environmental suitability for a rare and threatened species (Lao Newt, Laotriton laoensis) using validated species distribution models. PLOS ONE 8: e59853.

Cruz-García, K., D. F. Cisneros-Heredia, J. C. SánchezNivicela, and L. Amador. 2020. New records of four reptile species (Lepidosauria, Squamata) from Guayas province, southwestern Ecuador. Check List 16: 765-772.

Davies, K. F., C. R. Margules, and J. F. Lawrence. 2004. A synergistic effect puts rare, specialized species at greater risk of extinction. Ecology 85: 265-271.

Dinerstein, E., D. Olson, A. Joshi, C. Vynne, N. D. Burgess, E. Wikramanayake, N. Hahn, S. Palminteri, P. Hedao, R. Noss, M. Hansen, H. Locke, E. C. Ellis, B. Jones, C. V. Barber, R. Hayes, C. Kormos, V. Martin, E. Crist, W. Sechrest, L. Price, J. E. M. Baillie, D. Weeden, K. Suckling, C. Davis, N. Sizer, R. Moore, D. Thau, T. Birch, P. Potapov, S. Turubanova, A. Tyukavina, N. de Souza, L. Pintea, J. C. Brito, O. A. Llewellyn, A. G. Miller, A. Patzelt, S. A. Ghazanfar, J. Timberlake, H. Klöser, Y. Shennan-Farpón, R. Kindt, J.-P. B. Lilles $\varnothing$, P. van Breugel, L. Graudal, M. Voge, K. F. Al-Shammari, and M. Saleem. 2017. An ecoregion-based approach to protecting half the terrestrial realm. Bioscience 67: 534545 .

Duellman, W. E. 1990. Herpetofaunas in Neotropical rainforests: comparative composition, history, and resource use. Pp. 455-505 in A. H. Gentry (ed.), Four Neotropical Rainforests. New Haven. Yale University Press.

Dudley, N. (eds.). 2008. Guidelines for Applying Protected Area Management Categories. Gland. International Union for Conservation of Nature. 86 pp.

Eckert, C., K. Samis, and S. Lougheed. 2008. Genetic variation across species' geographical ranges: the central-marginal hypothesis and beyond. Molecular Ecology 17: 1170-1188.

Elith, J. and J. R. Leathwick. 2009. Species distribution models: ecological explanation and prediction across space and time. Annual Review of Ecology, Evolution, and Systematics 40: 677-697.

Elith, J., M. Kearney, and S. Phillips. 2010. The art of modelling range-shifting species. Methods in Ecology and Evolution 1: 330-342.
Elith, J., S. J. Phillips, T. Hastie, M. Dudík, Y. E. Chee, and C. J. Yates. 2011. A statistical explanation of MaxEnt for ecologists. Diversity and Distributions 17: 43-57.

Fagua, J. C., J. A. Baggio, and R. D. Ramsey. 2019. Drivers of forest cover changes in the Chocó-Darien Global Ecoregion of South America. Ecosphere 10: e02648.

Fatima, S. H., S. Atif, S. B. Rasheed, F. Zaidi, and E. Hussain. 2016. Species distribution modelling of Aedes aegypti in two dengue-endemic regions of Pakistan. Tropical Medicine and International Health 21: 427-436.

Feeney, R. (ed.). 2018. LACM Vertebrate Collection. Version 18.3. Electronic Database accessible at https:// doi.org/10. 15468/77rmwd/ Natural History Museum of Los Angeles County, Los Angeles, USA. Captured on 11 June 2019.

Flores, E. E., V. de Gracia, and B. Peña. 2016. Rhinobothryum bovallii (False Tree Coral). Geographic Distribution. Herpetological Review 47: 429.

Flórez-Jaramillo, L. A. and E. Barona-Cortés. 2016. Diversity of reptiles associated with three contrasting areas in a Tropical Dry Forest (La Dorada and Victoria, Caldas). Revista de Ciencias 20: 109-123.

Franklin, J., K. E. Wejnert, S. A. Hathaway, C. J. Rochester, and R. N. Fisher. 2009. Effect of species rarity on the accuracy of species distribution models for reptiles and amphibians in southern California. Diversity and Distributions 15: 167-177.

Galante, P. J., B. Alade, R. Muscarella, S. A. Jansa, S. M. Goodman, and R. P. Anderson. 2018. The challenge of modeling niches and distributions for data-poor species: a comprehensive approach to model complexity. Ecography 41: 726-736.

Garzón, N. V. and J. C. Gutiérrez (eds.). 2013. Deterioro de Humedales en el Magdalena Medio: un Llamado para su Conservación. Bogotá. Fundación Alma and Instituto de Investigación de Recursos Biológicos Alexander von Humboldt. 145 pp.

Gomes de Arruda, L. A., M. A. Carvalho, and R. A. Kawashita-Ribeiro. 2015. New records of the Amazon banded snake Rhinobothryum lentiginosum (Serpentes: Colubridae) from Mato Grosso state, Brazil, with natural history notes. Salamandra 51: 199-205.

Gregory-Wodzicki, K. M. 2000. Uplift history of the Central and Northern Andes: a review. Geological Society of America Bulletin 112: 1091-1105.

Hardie D. C. and J. A. Hutchings. 2010. Evolutionary ecology at the extremes of species' ranges. Environmental Reviews 18: 1-20.

Helgen, K., M. Pinto, R. Kays, L. Helgen, M. Tsuchiya, A. Quinn, D. Wilson, and J. Maldonado. 2013. Taxonomic 
revision of the olingos (Bassaricyon), with description of a new species, the Olinguito. ZooKeys 324: 1-83.

Hernández-Camacho, J. and H. Sánchez. 1992. Biomas terrestres de Colombia. Pp. 153-190 in G. Halffter (ed.), La Diversidad Biológica Iberoamericana I. Mexico City. Acta Zoológica Mexicana.

Hernández-Camacho, J., T. R. Walschburger, R. Ortiz-Quijano, and A. Hurtado-Guerra. 1992. Origen y distribución de la biota suramericana y colombiana. Pp. 55-104 in G. Halffter (ed.), La Diversidad Biológica Iberoamericana I. Mexico City. Acta Zoológica Mexicana.

Hijmans, R. J., S. E. Cameron, J. L. Parra, G. Jones, and A. Jarvis. 2005. Very high-resolution interpolated climate surfaces for global land areas. International Journal of Climatology 25: 1965-1978.

Hughey, K. F. D., R. Cullen, and E. Moran. 2003. Integrating economics into priority setting and evaluation in conservation management. Conservation Biology 17: $93-103$.

Karl, J. W., L. K. Svancara, P. J. Heglund, N. M. Wright, and J. M. Scott. 2002. Species commonness and the accuracy of habitat relationship models. Pp. 573-580 in J. M. Scott, P. J. Heglund, M. L. Morrison, J. B. Haufler, M. G. Raphael, W. A. Wall, and F. B. Samson (eds.), Predicting Species Occurrences: Issues of Accuracy and Scale. Washington DC. Island Press.

La Marca, E. (ed.). 1997. Origen y Evolución Geológica de la Cordillera de Mérida. Mérida. Universidad de Los Andes Press. 110 pp.

Lazala, M. 2007. Geología. Pp. 43-61 in J. O. Rangel (ed.), Colombia Diversidad Biótica V: La Alta Montaña de la Serranía de Perijá, Colombia. Bogotá . Instituto de Ciencias Naturales.

Leenders, T. 2017. Amphibians and Reptiles of Cocobolo Nature Reserve. New York. Roger Tory Peterson Institute of Natural History. 56 pp.

Lotzkat, S. 2014. Diversity, taxonomy, and biogeography of the reptiles inhabiting the highlands of the Cordillera Central (Serranía de Talamanca and Serranía de Tabasará) in western Panama. Unpublished Ph.D. Dissertation. Goethe-Universität, Germany.

Lynch, J. D., T. Angarita-Sierra, and F. J. Ruiz-Gómez (eds.). 2016. Programa Nacional para la Conservación de las Serpientes Presentes en Colombia. Bogotá. Ministerio de Medio Ambiente de Colombia. 128 pp.

Martínez-Fonseca, J. G., J. Loza, M. Fernández, M. Salazar-Saavedra, and J. Sunyer. 2019. First country record of Rhinobothryum bovallii (Andersson, 1916) (Squamata, Colubridae) from Nicaragua. Check List 15: 555-563.
Martins, M. and M. E. Oliveira. 1998. Natural history of snakes in forests of the Manaus region, central Amazonia, Brazil. Herpetological Natural History 6: $78-150$.

McConnell, G. J. (ed.). 2014. A Field Guide to the Snakes of Costa Rica. Frankfurt. Edition Chimaira. 233 pp.

McCranie, J. R. 2015. A checklist of the amphibians and reptiles of Honduras, with additions, comments on taxonomy, some recent taxonomic decisions, and areas of further studies needed. Zootaxa 3931: 352-386.

Meza-Joya, F. L., E. Ramos, F. Cediel, V. Martínez-Arias, J. Colmenares, and D. Cardona. 2018. Predicted distributions of two poorly known small carnivores in Colombia: the Greater Grison and Striped Hog-nosed Skunk. Mastozoología Neotropical 25: 89-105.

Miranda, D. B., S. Albuquerque, and N. M. Venâcio. 2009. Reptilia, Squamata, Colubridae, Rhinobothryum lentiginosum (Scopoli 1785): first record from state of Acre, Brazil. Check List 5: 917-918.

Mittermeier, R. A., P. R. Gil, M. Hoffmann, J. Pilgrim, T. Brooks, C. G. Mittermeier, J. Lamoreux, and G. A. B. Fonseca (eds.). 2004. Hotspots revisited: Earth's Biologically Richest and Most Endangered Ecoregions. Mexico City. Agrupación Sierra Madre. 392 pp.

Molloy, S. W., R. A. Davis, and E. J. B. Van Etten. 2014. Species distribution modelling using bioclimatic variables to determine the impacts of a changing climate on the western ringtail possum (Pseudocheirus occidentals; Pseudocheiridae). Environmental Conservation 41: 176-186.

Montingelli, G. G., F. G. Grazziotin, J. Battilana, R. W. Murphy, Y.-P. Zhang, and H. Zaher. 2019. Higher-level phylogenetic affinities of the Neotropical genus Mastigodryas Amaral, 1934 (Serpentes: Colubridae), species-group definition and description of a new genus for Mastigodryas bifossatus. Journal of Zoological Systematics and Evolutionary Research 57: 205-239.

Morris, P. J. (ed.). 2018. Museum of Comparative Zoology, Harvard University. Version 162.129. Electronic Database accessible at https://doi.org/10.15468/p5rupv/ Museum of Comparative Zoology, Cambridge, USA. Captured on 11 June 2019.

Nogueira, C., S. Ribeiro, G. C. Costa, and G. R. Colli. 2011. Vicariance and endemism in a Neotropical savanna hotspot: distribution patterns of Cerrado squamate reptiles. Journal of Biogeography 38: 1907-1922.

Norton, B. (ed.). 2018. NCSM Herpetology Collection. Version 26.2. Electronic Database accessible at https:// doi.org/10.15468/enivwl/ North Carolina State Museum of Natural Sciences, Raleigh, USA. Captured on 19 November 2019. 
Ochoa-Ochoa, L. M., P. Rodríguez, F. Mora, O. FloresVillela and R. J. Whittaker. 2012. Climate change and amphibian diversity patterns in Mexico. Biological Conservation 150: 94-102.

Pazmiño-Otamendi, G. (ed.). 2019. Rhinobothryum bovallii. Reptiles del Ecuador. Version 2019.0. Electronic Database accessible at https://bioweb.bio/faunaweb/ reptiliaweb/ Museo de Zoología, Pontificia Universidad Católica del Ecuador, Quito, Ecuador. Captured on 19 November 2019.

Pearson, R. G., C. J. Raxworthy, M. Nakamura, and A. T. Peterson. 2007. Predicting species distributions from small numbers of occurrence records: a test case using cryptic geckos in Madagascar. Journal of Biogeography 34: 102-117.

Peterman, W. E., S. M. Feist, R. D. Semlitsch, and L. S. Eggert. 2013. Conservation and management of peripheral populations: spatial and temporal influences on the genetic structure of wood frog (Rana sylvatica) populations. Biological Conservation 158: 351-358.

Peters, J. A. and B. Orejas-Miranda. 1970. Catalogue of the Neotropical Squamata: part I. Snakes. Bulletin of the United States National Museum 297: 1-347.

Peterson, A. T. 2006. Ecologic niche modeling and spatial patterns of disease transmission. Emerging Infectious Diseases 12: 1822-1826.

Peterson, A. T. and J. Soberón. 2012. Species distribution modeling and ecological niche modeling: getting the concepts right. Natureza and Conservação 10: 102-107.

Peterson, A. T., J. Soberón, R. G. Pearson, R. P. Anderson, E. Martínez-Meyer, M. Nakamura, and M. B. Araújo. 2011. Ecological Niches and Geographic Distributions. Princeton. Princeton University Press. 328 pp.

Phillips, S. J. and M. Dudík. 2008. Modeling of species distributions with Maxent: new extensions and a comprehensive evaluation. Ecography 31: 161-175.

Phillips, S. J., R. P. Anderson, and R. E. Schapire. 2006. Maximum entropy modeling of species geographic distributions. Ecological Modelling 190: 231-259.

Pokharel, K. P., T. Ludwig, and I. Storch. 2016. Predicting potential distribution of poorly known species with small database: the case of four-horned antelope Tetracerus quadricornis on the Indian subcontinent. Ecology and Evolution 6: 2297-2307.

Pomara, L. Y., K. Ruokolainen, and K. R. Young. 2014. Avian species composition across the Amazon River: the roles of dispersal limitation and environmental heterogeneity. Journal of Biogeography 41: 784-796.

Pons, A. R. 1965. Rhinobothryum bovallii Andersson género y especie de ofidio nuevo para Venezuela. Kasmera 2: 99-103.
Rabinowitz, D. 1981. Seven forms of rarity. Pp. 205-217 in H. Synge (ed.), The Biological Aspects of Rare Plant Conservation. Chichester. John Wiley and Sons.

Radosavljevic, A. and R. P. Anderson. 2014. Making better Maxent models of species distributions: complexity, overfitting and evaluation. Journal of Biogeography 41: 629-643.

Ramírez-Pinilla, M. P. and E. Meneses-Pelayo (ed.). 2020. Colección Herpetológica (Reptiles) del Museo de Historia Natural de la Universidad Industrial de Santander. Version 1.2. Electronic Database accessible at https://doi.org/10.15472/f4mjt8/ Universidad Industrial de Santander, Bucaramanga, Colombia. Captured on 19 November 2019.

Ramos, E., F. L. Meza-Joya, and C. Hernández-Jaimes. 2018. Distribution and conservation status of Andinobates virolinensis (Dendrobatidae), a threatened Andean poison frog endemic to Colombia. Herpetological Conservation and Biology 13: 58-69.

Rangel-Ch., O. and H. Arellano-P. 2004. Clima del Chocó Biogeográfico / Costa Pacífica de Colombia. Pp. 39-82 in O. Rangel-Ch. (ed.), Diversidad Biótica IV. El Chocó Biogeográfico / Costa Pacífica. Bogotá. Universidad Nacional de Colombia, Instituto de Ciencias Naturales, and Conservación Internacional.

Raxworthy, C. J., E. Martinez-Meyer, N. Horning, R. A. Nussbaum, G. E. Schneider, M. A. Ortega-Huerta, and T. Peterson. 2003. Predicting distributions of known and unknown reptile species in Madagascar. Nature 426: $837-841$.

Ray, J. M. and P. Ruback. 2015. Updated checklists of snakes for the Provinces of Panamá and Panamá Oeste, Republic of Panama. Mesoamerican Herpetology 2: $168-188$.

Rengifo, J. T. and Y. L. Pino (eds.). 2018. Colección Científica de Referencia Zoológica del Chocó. Version 17.1. Electronic Database accessible at https://doi. org/10.15472/sz411m/ Universidad Tecnológica del Chocó, Quibdó, Colombia. Captured on 19 November 2019.

Rödder, D. and S. Lötters. 2010. Potential distribution of the alien invasive brown tree snake, Boiga irregularis (Reptilia: Colubridae). Pacific Science 64: 11-22.

Rojas-Morales, J. A. 2012. On the geographic distribution of the false coral snake, Rhinobothryum bovallii (Serpentes: Dipsadidae), in Colombia. A biogeographical perspective. Salamandra 48: 243-248.

Rojas-Runjaic, F. J. and E. E. Infante-Rivero. 2018. Redescubrimiento de las serpientes Rhinobothryum bovallii (Andersson, 1916) y Plesiodipsas perijanensis (Alemán, 1953) en Venezuela. Memoria de la Fundación La Salle de Ciencias Naturales 76: 83-92. 
Sabaj-Perez, M. H. (ed.). 2016. Standard symbolic codes for institutional resource collections in herpetology and ichthyology: an Online Reference. Electronic Database accessible at http://www.asih.org/standard-symboliccodes/ American Society of Ichthyologists and Herpetologists, Lawrence, USA. Captured on 11 June 2019.

Salinas, S. and A. Valencia-Aguilar (eds.). 2018. Colección de anfibios y reptiles del Laboratorio de Herpetología de la Universidad del Valle. Version 14.1. Electronic Database accessible at https://doi.org/10.15472/4nryow/ Universidad del Valle, Cali, Colombia. Captured on 19 November 2019.

Savage, J. M. (ed.) 2002. The Amphibians and Reptiles of Costa Rica: a Herpetofauna Between Two Continents, Between Two Seas. Chicago. University of Chicago Press. 934 pp.

Shcheglovitova, M. and R. P. Anderson. 2013. Estimating optimal complexity for ecological niche models: a jackknife approach for species with small sample sizes. Ecological Modelling 269: 9-17.

Smith, B. T., J. E. McCormack, A. M. Cuervo, M. J. Hickerson, A. Aleixo, C. D. Cadena, J. Pérez-Emán, C. W. Burney, X. Xie, M. G. Harvey, B. C. Faircloth, T. C. Glenn, E. P. Derryberry, J. Prejean, S. Fields, and R. T. Brumfield. 2014. The drivers of tropical speciation. Nature 515: 406-409.

Steinke, J. A. 2016. A comparative study of herpetofauna in a primary forest and reforested area in coastal Ecuador. Journal of Young Investigators 30: 14-19.

Turcios-Casco, M. A., J. Ramos Galdámez, M. SalazarSaavedra, and J. R. McCranie. 2018. A second locality for Rhinobothryum bovallii Andersson (Colubridae) in Nuclear Central America, with comments on its habitat. Mesoamerican Herpetology 5: 138-144.

Urbina-Cardona, J. N. and F. Castro. 2010. Distribución actual y futura de anfibios y reptiles con potencial invasor en Colombia: una aproximación usando modelos de nicho ecológico. Pp. 65-72 in A. Varela (ed.), Biodiversidad y Cambio Climático. Bogotá. Pontificia Universidad Javeriana.

Vega, R., C. Fløjgaard, A. Lira-Noriega, Y. Nakazawa, J. C. Svenning, and J. B. Searle. 2010. Northern glacial refugia for the pygmy shrew Sorex minutus in Europe revealed by phylogeographic analyses and species distribution modelling. Ecography 33: 260-271.

Velásquez-Tibatá, J., P. Salaman, and C. H. Graham. 2013. Effects of climate change on species distribution, community structure, and conservation of birds in protected areas in Colombia. Regional Environmental Change 13: 235-248.
Vera-Pérez, L. E., J. A. Zúñiga-Baos, and E. Alzate-Basto. 2019. Rhinobothryum bovallii (Andersson, 1916) (Serpentes: Colubridae): nuevas localidades para Colombia, descripción hemipeneal y comentarios sobre su historia natural. Revista Novedades Colombianas 14: $57-68$.

Van der Hammen, T. and H. Hooghiemstra. 2000. Neogene and Quaternary history of vegetation, climate and plant diversity in Amazonia. Quaternary Science Reviews 19: 725-742.

Wallach, V., K. L. Williams, and J. Boundy. 2014. Snakes of the World: a Catalogue of Living and Extinct Species. Boca Raton. CRC Press. 1227 pp.

Waltari, E., R. J. Hijmans, A. T. Peterson, Á. S. Nyári, S. L. Perkins, and R. P. Guralnick. 2007. Locating Pleistocene refugia: comparing phylogeographic and ecological niche model predictions. PLOS ONE 2: e563.

Warren, D. L., R. E. Glor, and M. Turelli. 2010. ENMTools: a toolbox for comparative studies of environmental niche models. Ecography 33: 607-611.

Warren, D. L., A. N. Wright, S. N. Seifert, and H. B. Shaffer. 2014. Incorporating model complexity and spatial sampling bias into ecological niche models of climate change risks faced by 90 California vertebrate species of concern. Diversity and Distributions 20: 334-343.

Wilson, L. D. and J. R. McCranie. 2003. Herpetofaunal indicator species as measures of environmental stability in Honduras. Caribbean Journal of Science 39: 50-67.

Winterton, C., J. E. Richardson, M. Hollingsworth, A. Clark, N. Zamora, and R. T. Pennington. 2014. Historical biogeography of the Neotropical legume genus Dussia: the Andes, the Panama Isthmus and the Chocó. Pp. 389-404 in W. D. Stevens, O. M. Montiel and P. Raven (eds.), Paleobotany and Biogeography: a Festschrift for Alan Graham in His $80^{\text {th }}$ Year. Saint Louis. Missouri Botanical Press.

Zaher, H., F. E. Barbo, P. S. Martínez, C. Nogueira, M. T. Rodrigues, and R. J. Sawaya. 2011. Répteis do estado de São Paulo: conhecimento atual e perspectivas. Biota Neotropica 11: 1-15.

Zaher, H., R. W. Murphy, J. C. Arredondo, R. Graboski, P. R. Machado-Filho, K. Mahlow, G. G. Montingelli, A. B. Quadros, N. L. Orlov, M. Wilkinson, Y.-P. Zhang, and F. G. Grazziotin. 2019. Large-scale molecular phylogeny, morphology, divergence-time estimation, and the fossil record of advanced caenophidian snakes (Squamata: Serpentes). PLoS ONE 14: e0216148.

Editor: Philippe J. R. Kok 
Appendix I. Confirmed locality records for Rhinobothryum bovallii. Records are ordered in a latitudinal gradient. Institutional codes for museum collections follow those of Sabaj-Perez (2016), except for Circulo Herpetológico de Panamá, Panama (CH), Colección Herpetológica of the Museo de Historia Natural at Universidad de Caldas, Colombia (MHN-UCa), Colección Zoológica Dr. Eustorgio Méndez del Instituto Conmemorativo Gorgas de Estudios de la Salud, Panama (COZEM), Museo de Historia Natural de la Universidad del Cauca, Colombia (MHNUC), University of Kansas Biodiversity Institute Herpetological Collection, USA (KU), University of Texas at Arlington Digital Collection, USA (UTADC). Elevations ( $m$ a.s.l.) in bold were estimated from geographic coordinates. Geographic coordinates are provided in decimal degrees

(as used to build the models) in the WGS-84 datum. *Type locality, coordinates from Martinez-Fonseca et al. (2019).

${ }^{1}$ Coordinates by M. A. Turcios-Casco. ${ }^{2}$ Coordinates from Martinez-Fonseca et al. (2019). ${ }^{3}$ Coordinates from Helgen et al. (2013). ${ }^{4}$ Coordinates from Cadle (2012). ${ }^{5}$ Coordinates estimated or corrected based on the locality provided by the source.

${ }^{6}$ Locality corrected based on the coordinates provided by the source. ${ }^{7}$ Coordinates from the online catalog of the herpetological collection where the specimen voucher is deposited.

\begin{tabular}{|c|c|c|c|c|c|}
\hline Locality & Record type & Latitude & Longitude & $\begin{array}{c}\text { Elevation } \\
\text { (m a.s.l.) }\end{array}$ & Source \\
\hline \multicolumn{6}{|l|}{ Honduras } \\
\hline $\begin{array}{l}\text { Gracias a Dios, The Lost City of the } \\
\text { Monkey God }\end{array}$ & UVS-V-01080 & 15.245244 & -84.965346 & 204 & $\begin{array}{l}\text { Turcios-Casco et al. } \\
2018\end{array}$ \\
\hline El Paraíso, Trojes, near Arenales ${ }^{1}$ & LACM 20488 & 13.934110 & -85.812119 & 467 & $\begin{array}{l}\text { Campbell and } \\
\text { Howell } 1965\end{array}$ \\
\hline \multicolumn{6}{|l|}{ Nicaragua } \\
\hline $\begin{array}{l}\text { Río San Juan, Reserva de la Biósfera } \\
\text { Río San Juán, Refugio Bartola }\end{array}$ & UMMZ 247120 & 10.970686 & -84.333780 & 65 & $\begin{array}{c}\text { Martínez-Fonseca et } \\
\text { al. } 2019\end{array}$ \\
\hline \multicolumn{6}{|l|}{ Costa Rica } \\
\hline Alajuela, Pital, Laguna Lagarto & Photograph & 10.687000 & -84.180900 & 38 & iNaturalist 2648512 \\
\hline Limón, Siquirres, near El Carmen² & Distribution map & 10.210000 & -83.460000 & 20 & Savage 2002 \\
\hline Limón, Siquirres, near Encanto ${ }^{2}$ & Distribution map & 10.190000 & -83.390000 & 10 & Savage 2002 \\
\hline $\begin{array}{l}\text { Limón, Siquirres, near El Peje de } \\
\text { Cairo }^{2}\end{array}$ & Distribution map & 10.170000 & -83.510000 & 23 & Savage 2002 \\
\hline Limón, Siquirres, near La Lucha² & Distribution map & 10.160000 & -83.440000 & 19 & Savage 2002 \\
\hline Limón, Siquirres, near La Florida² & Distribution map & 10.100000 & -83.580000 & 266 & Savage 2002 \\
\hline Limón, Siquirres* & GNM 1221 & 10.100000 & -83.510000 & 81 & Andersson 1916 \\
\hline Limón, Siquirres, near El Coco & Photograph & 10.090437 & -83.541017 & 228 & iNaturalist 1562800 \\
\hline Limón, Siquirres, near Guayacán² & Photograph & 10.040000 & -83.530000 & 565 & Savage 2002 \\
\hline Limón, Siquirres, Pacuare River & NCSM 84544 & 9.998700 & -83.542400 & 243 & Norton 2018 \\
\hline Limón, Siquirres, 3 km NE Tres Equis & LACM 154272 & 9.990613 & -83.570140 & 500 & Feeney 2018 \\
\hline $\begin{array}{l}\text { Limón, Valle de La Estrella, near } \\
\text { Bananito Sur }{ }^{2}\end{array}$ & Distribution map & 9.850000 & -82.970000 & 20 & Savage 2002 \\
\hline Limón, Banano River Basin² & Distribution map & 9.840000 & -83.190000 & 1025 & Savage 2002 \\
\hline Limón, Talamanca, near Bribrí & Distribution map & 9.680000 & -82.880000 & 162 & Savage 2002 \\
\hline Limón, Talamanca, near Shiroles ${ }^{2}$ & Distribution map & 9.600000 & -82.960000 & 188 & Savage 2002 \\
\hline \multicolumn{6}{|l|}{ Panama } \\
\hline Colón, Portobelo, Cerro Bruja & $\begin{array}{l}\text { LACM-R 2380- } \\
\qquad 84\end{array}$ & 9.471734 & -79.567519 & 946 & This study \\
\hline $\begin{array}{l}\text { Bocas del Toro, Changuinola, La } \\
\text { Gloria }^{2}\end{array}$ & Reported & 9.460000 & -82.440000 & 9 & Lotzkat 2014 \\
\hline Panamá, Parque Nacional Chagres ${ }^{2}$ & Distribution map & 9.430000 & -79.430000 & 350 & $\begin{array}{c}\text { Ray and Ruback } \\
2015\end{array}$ \\
\hline
\end{tabular}


Appendix I. Continued.

\begin{tabular}{|c|c|c|c|c|c|}
\hline Locality & Record type & Latitude & Longitude & $\begin{array}{l}\text { Elevation } \\
\text { (m a.s.l.) }\end{array}$ & Source \\
\hline Guna Yala, Llano Carti, Burbayar ${ }^{2}$ & Photograph & 9.420000 & -79.000000 & 54 & McConnell 2014 \\
\hline Panamá, Parque Nacional Chagres ${ }^{2}$ & MCZ R-50220 & 9.360000 & -79.440000 & 496 & $\begin{array}{l}\text { Ray and Ruback } \\
2015\end{array}$ \\
\hline $\begin{array}{l}\text { Guna Yala, Narganá, footpath } \\
\text { Nusagandi }\end{array}$ & CH 08759 & 9.344417 & -78.996390 & 335 & This study \\
\hline $\begin{array}{l}\text { Guna Yala, Cerro Brewster, Parque } \\
\text { Nacional Chagres }\end{array}$ & CH 06095 & 9.321585 & -79.282010 & 872 & EMBL-EBI 2019 \\
\hline $\begin{array}{l}\text { Colón, Boyd-Roosevelt Highway, near } \\
\text { Rita River }\end{array}$ & UMMZ 147770 & 9.320000 & -79.790000 & 151 & $\begin{array}{c}\text { Martínez-Fonseca et } \\
\text { al. } 2019\end{array}$ \\
\hline $\begin{array}{l}\text { Panamá, Chepo, Zahinas, Cocobolo } \\
\text { Nature Reserve }^{2}\end{array}$ & Photograph & 9.300000 & -79.210000 & 444 & Leenders 2017 \\
\hline $\begin{array}{l}\text { Colón, } 19 \text { Km NW Gamboa, Canal } \\
\text { Zone (navy Pipeline Road) }\end{array}$ & $\begin{array}{l}\text { COZEM-REP } \\
0372\end{array}$ & 9.242696 & -79.822077 & 61 & This study \\
\hline Colón, Pipeline Road & CH 07631 & 9.170808 & -79.753484 & 136 & This study \\
\hline Panamá, Road to Tortí & CH 10437 & 9.160108 & -78.698850 & 90 & This study \\
\hline Colón, Gamboa, Canal Zone & $\begin{array}{l}\text { COZEM-REP } \\
0371\end{array}$ & 9.125603 & -79.704555 & 156 & This study \\
\hline Panamá, Panamá city, Canal Zone ${ }^{2}$ & MCZ R-45404 & 9.000000 & -79.550000 & 63 & Morris 2018 \\
\hline $\begin{array}{l}\text { Bocas del Toro, Changuinola River } \\
\text { basin }^{2}\end{array}$ & Reported & 8.950000 & -82.439000 & 950 & Lotzkat 2014 \\
\hline Guna Yala, San Blás, Sasardi camp ${ }^{3}$ & KU 112463-64 & 8.950000 & -77.817000 & 41 & Brown 2018 \\
\hline Guna Yala, San Blás, Summit camp ${ }^{4}$ & KU 112462 & 8.916000 & -77.850000 & 361 & Brown 2018 \\
\hline Colón, Donoso, Petaquiya stream & Photograph & 8.826253 & -80.678855 & 180 & This study \\
\hline $\begin{array}{l}\text { Coclé, La Pintada, El Copé, near Omar } \\
\text { Torrijos National Park }\end{array}$ & $\mathrm{CH} 05938$ & 8.662691 & -80.590435 & 712 & EMBL-EBI 2019 \\
\hline Panamá Oeste, near Altos del María ${ }^{5}$ & Observation & 8.662151 & -80.003867 & 276 & $\begin{array}{l}\text { Ray and Ruback } \\
2015\end{array}$ \\
\hline $\begin{array}{l}\text { Coclé, La Pintada, El Copé, near Omar } \\
\text { Torrijos National Park }\end{array}$ & Photograph & 8.644611 & -80.589944 & 926 & iNaturalist 1309822 \\
\hline $\begin{array}{l}\text { Chiriquí, Boquerón, Bágala, Cerro } \\
\text { Colorado, Escopeta camp }\end{array}$ & USNM 297732 & 8.518700 & -82.537100 & 900 & USNM \\
\hline $\begin{array}{l}\text { Darién, Ucurganti River, ca } 7 \text { km } \\
\text { above mouth }{ }^{2}\end{array}$ & KU 112461 & 8.510000 & -77.800000 & 46 & Brown 2018 \\
\hline $\begin{array}{l}\text { Veraguas, Rasca River, above El } \\
\text { Paredón }{ }^{6}\end{array}$ & SMF 91577 & 8.491000 & -81.169400 & 775 & Lotzkat 2014 \\
\hline Veraguas, Santa Fé, Cerro Tute & SMF 90022 & 8.488140 & -81.109840 & 1116 & Carrizo 2010 \\
\hline Darien, Río Tuira at Río Mono² & KU 112460 & 8.460000 & -78.130000 & 96 & Brown 2018 \\
\hline Veraguas, Calobre, La Laguna & $\begin{array}{l}\text { COZEM-REP } \\
0370\end{array}$ & 8.455487 & -80.851749 & 651 & This study \\
\hline $\begin{array}{l}\text { Darién, Pinogana, Reserva Forestal } \\
\text { Canglón }\end{array}$ & $\mathrm{CH} 00535$ & 8.266388 & -77.796801 & 17 & This study \\
\hline $\begin{array}{l}\text { Darién, Serranía del Bagre, Reserva } \\
\text { Chepigana de Darién }{ }^{2}\end{array}$ & Reported & 8.220000 & -78.000000 & 20 & $\begin{array}{c}\text { Martínez-Fonseca et } \\
\text { al. } 2019\end{array}$ \\
\hline Darién, Pinogana, Yaviza & MCZ R-38236 & 8.152900 & -77.697300 & 10 & Morris 2018 \\
\hline
\end{tabular}


Meza-Joya et al.

Appendix I. Continued.

\begin{tabular}{|c|c|c|c|c|c|}
\hline Locality & Record type & Latitude & Longitude & $\begin{array}{l}\text { Elevation } \\
\text { (m a.s.l.) }\end{array}$ & Source \\
\hline Darién, Tacarcuna ${ }^{2}$ & KU 75749 & 8.170000 & -77.270000 & 1535 & Brown 2018 \\
\hline $\begin{array}{l}\text { Veraguas, Mariato, Cerro Hoya } \\
\text { National Park }\end{array}$ & UTADC 8654 & 7.345690 & -80.691330 & 533 & Flores et al. 2016 \\
\hline $\begin{array}{l}\text { Los Santos, Tonosí, Ave María, } \\
\text { Guanico River }\end{array}$ & KU 107839 & 7.316700 & -80.466700 & 104 & Brown 2018 \\
\hline \multicolumn{6}{|l|}{ Colombia } \\
\hline $\begin{array}{l}\text { La Guajira, Dibulla, Pozo Azul, Santa } \\
\text { Rita de la Sierra }\end{array}$ & Specimen & 11.193333 & -73.267000 & 124 & This study \\
\hline $\begin{array}{l}\text { Magdalena, Santa Marta, Minca, } \\
\text { Arimaca }\end{array}$ & Photograph & 11.115820 & -74.124465 & 843 & iNaturalist 16216599 \\
\hline $\begin{array}{l}\text { Bolivar, San Juán Nepomuceno, } \\
\text { Miraflores }\end{array}$ & Photograph & 9.925884 & -75.093211 & 167 & $\begin{array}{c}\text { Barreto-Martínez } \\
\text { and Rojas-Morales } \\
2020\end{array}$ \\
\hline $\begin{array}{l}\text { Cesar, La Jagua de Ibirico, La Victoria } \\
\text { de San Isidro }\end{array}$ & Observation & 9.595222 & -73.158861 & 623 & $\begin{array}{l}\text { Vera-Pérez et al. } \\
2019\end{array}$ \\
\hline $\begin{array}{l}\text { Sucre, Colosó, El Sereno Alto, El } \\
\text { Sereno stream }\end{array}$ & IAvH-R-5486 & 9.542939 & -75.340000 & 300 & Borja-Acosta 2017 \\
\hline $\begin{array}{l}\text { Córdoba, Tierralta, Palmira, La } \\
\text { Plumilla }\end{array}$ & ICN 053929 & 8.033056 & -76.170556 & 162 & Rojas-Morales 2012 \\
\hline Chocó, Unguía, Peye & UTCH 1172 & 7.920430 & -77.096770 & 40 & $\begin{array}{l}\text { Rengifo and Pino } \\
2018\end{array}$ \\
\hline Cesar, San Alberto, Miramar ${ }^{5}$ & ICN 054087a & 7.917869 & -73.401721 & 715 & $\begin{array}{c}\text { Rojas-Morales } \\
2012\end{array}$ \\
\hline Antioquia, Chigorodó, near Turbo & USNM 154026 & 7.670000 & -76.780000 & 10 & $\begin{array}{c}\text { Martínez-Fonseca et } \\
\text { al. } 2019\end{array}$ \\
\hline $\begin{array}{l}\text { Santander, Sabana de Torres, Reserva } \\
\text { Cabildo Verde }\end{array}$ & Photograph & 7.344955 & -73.500397 & 168 & This study \\
\hline Antioquia, Mutatá & MHUA-R 14276 & 7.247222 & -76.439167 & 140 & $\begin{array}{c}\text { Rojas-Morales } \\
2012\end{array}$ \\
\hline Bolívar, Cantagallo, Caguí & Photograph & 7.252528 & -74.033500 & 98 & This study \\
\hline Antioquia, Valdivia, La Habana & Observation & 7.238667 & -75.403556 & 642 & $\begin{array}{l}\text { Vera-Pérez et al. } \\
2019\end{array}$ \\
\hline $\begin{array}{l}\text { Antioquia, Briceño, between Ticuita } \\
\text { and Capitan stream }{ }^{7}\end{array}$ & MHUA-R 14703 & 7.112200 & -75.554200 & 1350 & $\begin{array}{l}\text { Rojas-Morales } \\
2012\end{array}$ \\
\hline Santander, Girón, Sogamoso & Specimen & 7.095583 & -73.382694 & 563 & This study \\
\hline Santander, Betulia, La Putana & Photograph & 7.094102 & -73.416165 & 398 & This study \\
\hline Santander, Girón, Sogamoso & Photograph & 7.090167 & -73.384389 & 457 & This study \\
\hline Antioquia, Toledo, La Cascarela & Observation & 7.085917 & -75.694333 & 381 & $\begin{array}{l}\text { Vera-Pérez et al. } \\
2019\end{array}$ \\
\hline $\begin{array}{l}\text { Santander, Girón, Sogamoso, Las } \\
\text { Cruces }\end{array}$ & UIS-R 2776 & 7.083218 & -73.383432 & 323 & $\begin{array}{c}\text { Ramírez-Pinilla and } \\
\text { Meneses-Pelayo } \\
2020\end{array}$ \\
\hline Antioquia, Toledo, El Valle & $\begin{array}{l}\text { MHNUC- } \\
\text { He-0713 }\end{array}$ & 7.041222 & -75.670694 & 523 & $\begin{array}{l}\text { Vera-Pérez et al. } \\
2019\end{array}$ \\
\hline
\end{tabular}


Appendix I. Continued.

\begin{tabular}{|c|c|c|c|c|c|}
\hline Locality & Record type & Latitude & Longitude & $\begin{array}{c}\text { Elevation } \\
\text { (m a.s.l.) }\end{array}$ & Source \\
\hline Antioquia, Sabanalarga, Orobajo & Observation & 7.025000 & -75.793194 & 394 & $\begin{array}{l}\text { Vera-Pérez et al. } \\
2019\end{array}$ \\
\hline $\begin{array}{l}\text { Santander, Betulia, Sogamoso, } \\
\text { Corintios }\end{array}$ & Photograph & 7.000917 & -73.393676 & 349 & This study \\
\hline $\begin{array}{l}\text { Santander, Betulia, Sogamoso, } \\
\text { Corintios }\end{array}$ & Photograph & 6.996707 & -73.416801 & 761 & This study \\
\hline Antioquia, Anorí, El Retiro ${ }^{7}$ & MHUA-R 14559 & 6.985000 & -75.089722 & 871 & $\begin{array}{c}\text { Rojas-Morales } \\
2012\end{array}$ \\
\hline $\begin{array}{l}\text { Antioquia, Anorí, Dam wall at Porce } \\
\text { III dam }\end{array}$ & Photograph & 6.938611 & -75.140219 & 633 & iNaturalist 41131 \\
\hline Antioquia, Amalfi, María Teresa & Photograph & 6.924417 & -75.142528 & 657 & $\begin{array}{l}\text { Vera-Pérez et al. } \\
2019\end{array}$ \\
\hline $\begin{array}{l}\text { Santander, El Carmen de Chucurí, } \\
\text { Riosucio }\end{array}$ & IAvH-ACX566 & 6.577139 & -73.573111 & 760 & $\begin{array}{l}\text { Acosta-Galvis and } \\
\text { Borja-Acosta } 2018\end{array}$ \\
\hline $\begin{array}{l}\text { Antioquia, Maceo, Las Brisas, Santa } \\
\text { Barbara farm }{ }^{7}\end{array}$ & MHUA-R 14583 & 6.546900 & -74.643600 & 577 & $\begin{array}{l}\text { Rojas-Morales } \\
2012\end{array}$ \\
\hline Antioquia, Puerto Berrío, Hermilda & Photograph & 6.411665 & -74.701710 & 687 & iNaturalist 8360221 \\
\hline Santander, Landazuri ${ }^{7}$ & ICN 054086 & 6.358611 & -73.899444 & 202 & $\begin{array}{l}\text { Rojas-Morales } \\
2012\end{array}$ \\
\hline Antioquia, Puerto Nare, Canteras & Observation & 6.278500 & -74.675908 & 214 & $\begin{array}{l}\text { Vera-Pérez et al. } \\
2019\end{array}$ \\
\hline $\begin{array}{l}\text { Antioquia, San Carlos, El Jordán, } \\
\text { Juanes, Casino Viejo }\end{array}$ & $\begin{array}{l}\text { ISAGEN 46- } \\
2978\end{array}$ & 6.219139 & -74.817139 & 717 & $\begin{array}{c}\text { Martínez-Fonseca et } \\
\text { al. } 2019\end{array}$ \\
\hline Santander, Sucre, La Tipa & UIS-R 4278 & 5.956132 & -74.065343 & 564 & $\begin{array}{c}\text { Ramírez-Pinilla and } \\
\text { Meneses-Pelayo } \\
2020\end{array}$ \\
\hline $\begin{array}{l}\text { Boyacá, Puerto Boyacá, Las Pavas, } \\
\text { Puerto Romero }{ }^{7}\end{array}$ & ICN 054085 & 5.843056 & -74.326667 & 359 & $\begin{array}{l}\text { Rojas-Morales } \\
2012\end{array}$ \\
\hline Antioquia, La Miel River ${ }^{2}$ & IAvH-R-5880-81 & 5.710000 & -74.730000 & 169 & Borja-Acosta 2017 \\
\hline $\begin{array}{l}\text { Caldas, Norcasia, Quiebra Roque, } \\
\text { Reserva Río Manso }\end{array}$ & Observation & 5.664167 & -74.785833 & 280 & $\begin{array}{l}\text { Rojas-Morales } \\
2012\end{array}$ \\
\hline Chocó, Atrato, San Martín de Purré & UTCH 0299 & 5.649520 & -76.579380 & 80 & $\begin{array}{l}\text { Rengifo and Pino } \\
2018\end{array}$ \\
\hline Chocó, Atrato, Samurindó & UTCH 0339 & 5.587500 & -76.654167 & 36 & $\begin{array}{l}\text { Rengifo and Pino } \\
2018\end{array}$ \\
\hline $\begin{array}{l}\text { Caldas, Norcasia, road to Berlín } \\
\text { (Samaná) }\end{array}$ & MHN-UC 0306 & 5.572690 & -74.904020 & 648 & This study \\
\hline $\begin{array}{l}\text { Caldas, Norcasia, Puerto Norcasia, } \\
\text { Amaní dam }\end{array}$ & MHN-UC 0238 & 5.564766 & -74.907133 & 550 & This study \\
\hline Caldas, Samaná, Cañaveral ${ }^{7}$ & MHUA-R 14142 & 5.537028 & -74.908694 & 623 & $\begin{array}{l}\text { Rojas-Morales } \\
2012\end{array}$ \\
\hline Chocó, Unión Panamericana, Salero & $\begin{array}{l}\text { UTCH } 1240, \\
1244\end{array}$ & 5.360278 & -76.645833 & 115 & $\begin{array}{l}\text { Rengifo and Pino } \\
2018\end{array}$ \\
\hline
\end{tabular}


Appendix I. Continued.

\begin{tabular}{|c|c|c|c|c|c|}
\hline Locality & Record type & Latitude & Longitude & $\begin{array}{l}\text { Elevation } \\
\text { (m a.s.l.) }\end{array}$ & Source \\
\hline $\begin{array}{l}\text { Caldas, La Dorada, Guarinocito, } \\
\text { Purnio }\end{array}$ & Photograph & 5.355227 & -74.798606 & 305 & $\begin{array}{c}\text { Flórez-Jaramillo and } \\
\text { Barona-Cortés } \\
2016\end{array}$ \\
\hline Caldas, Victoria, El Llano ${ }^{7}$ & MHUA-R 14785 & 5.329388 & -74.849305 & 289 & $\begin{array}{l}\text { Rojas-Morales } \\
2012\end{array}$ \\
\hline $\begin{array}{l}\text { Valle del Cauca, Buenaventura, San } \\
\text { Cipriano }\end{array}$ & Observation & 3.834167 & -76.890556 & 115 & $\begin{array}{l}\text { Rojas-Morales } \\
2012\end{array}$ \\
\hline $\begin{array}{l}\text { Valle del Cauca, Buenaventura, } \\
\text { Guamía }\end{array}$ & $\begin{array}{l}\text { UVC-13662, } \\
13685\end{array}$ & 3.731667 & -76.958333 & 41 & $\begin{array}{l}\text { Rojas-Morales } \\
2012\end{array}$ \\
\hline $\begin{array}{l}\text { Valle del Cauca, Buenaventura, Bajo } \\
\text { Anchicayá }\end{array}$ & UVC-9591 & 3.613741 & -76.910950 & 536 & $\begin{array}{c}\text { Salinas and } \\
\text { Valencia-Aguilar } \\
2018\end{array}$ \\
\hline $\begin{array}{l}\text { Valle del Cauca, Buenaventura, Bajo } \\
\text { Anchicayá dam }\end{array}$ & UVC-5266 & 3.533263 & -76.867508 & 702 & $\begin{array}{c}\text { Salinas and } \\
\text { Valencia-Aguilar } \\
2018\end{array}$ \\
\hline Huila, Gigante, La Honda & $\begin{array}{l}\text { MHNUC- } \\
\text { He-0693 }\end{array}$ & 2.369611 & -75.571722 & 725 & $\begin{array}{l}\text { Vera-Pérez et al. } \\
2019\end{array}$ \\
\hline \multicolumn{6}{|l|}{ VENEZUELA } \\
\hline $\begin{array}{l}\text { Zulia, Rosario de Perijá, Puerto Nuevo, } \\
\text { Cogollo River }\end{array}$ & MBLUZ R-486 & 10.346944 & -72.516111 & 350 & $\begin{array}{l}\text { Rojas-Runjaic and } \\
\text { Infante-Rivero } 2018\end{array}$ \\
\hline $\begin{array}{l}\text { Zulia, Kasmera, Yasa River basin, } \\
\text { Sierra de Perijá }\end{array}$ & MBLUZ R-182 & 9.943333 & -72.749167 & 270 & Pons 1965 \\
\hline $\begin{array}{l}\text { Zulia, Ipika, Tokuko River, Sierra de } \\
\text { Périjá }\end{array}$ & MHNLS 20940 & 9.881667 & -72.516111 & 560 & $\begin{array}{l}\text { Rojas-Runjaic and } \\
\text { Infante-Rivero } 2018\end{array}$ \\
\hline \multicolumn{6}{|l|}{ ECUADOR } \\
\hline $\begin{array}{l}\text { Esmeraldas, Eloy Alfaro, Playa de Oro, } \\
\text { Reserva Cotacachi Cayapas }\end{array}$ & QCAZ-R 10703 & 0.828464 & -78.722010 & 567 & $\begin{array}{l}\text { Pazmiño-Otamendi } \\
2019\end{array}$ \\
\hline Esmeraldas, Zapallo Grande & QCAZ-R 1595 & 0.773994 & -78.936000 & 487 & $\begin{array}{l}\text { Pazmiño-Otamendi } \\
2019\end{array}$ \\
\hline $\begin{array}{l}\text { Esmeraldas, Eloy Alfaro, Telembí, } \\
\text { Reserva Tesoro Escondido }\end{array}$ & QCAZ-R 15012 & 0.493760 & -79.136080 & 675 & $\begin{array}{l}\text { Pazmiño-Otamendi } \\
2019\end{array}$ \\
\hline $\begin{array}{l}\text { Manabí, Cuaque River, } 10 \text { min from } \\
\text { Pedernales, Canoa way }\end{array}$ & QCAZ-R 8962 & -0.021260 & -80.068930 & 25 & $\begin{array}{l}\text { Pazmiño-Otamendi } \\
2019\end{array}$ \\
\hline Manabí, 15 km Pedernales, Jama way & QCAZ-R 5757 & -0.078821 & -80.021630 & 36 & $\begin{array}{l}\text { Pazmiño-Otamendi } \\
2019\end{array}$ \\
\hline $\begin{array}{l}\text { Manabí, Jama, Reserva Ecológica } \\
\text { Jama-Coaque }\end{array}$ & QCAZ-R 4652 & -0.090978 & -80.147190 & 3 & $\begin{array}{l}\text { Pazmiño-Otamendi } \\
2019\end{array}$ \\
\hline $\begin{array}{l}\text { Manabí, Jama, Reserva Ecológica } \\
\text { Jama-Coaque }\end{array}$ & QCAZ-R 5889 & -0.109405 & -80.117529 & 392 & $\begin{array}{l}\text { Pazmiño-Otamendi } \\
2019\end{array}$ \\
\hline $\begin{array}{l}\text { Manabí, Jama, Reserva Ecológica } \\
\text { Jama-Coaque }\end{array}$ & No voucher & -0.110156 & -80.128183 & 278 & Steinke 2016 \\
\hline $\begin{array}{l}\text { Guayas, Naranjal, Molleturo- } \\
\text { Mollepungo, Cerro de Hayas }\end{array}$ & ZSFQ 4081 & -2.730800 & -79.628600 & 110 & $\begin{array}{c}\text { Cruz-García et al. } \\
2020\end{array}$ \\
\hline
\end{tabular}

